\title{
ANÁLISE DAS COMPETÊNCIAS NECESSÁRIAS AOS MEMBROS DO COLEGIADO PLENO DO PROGRAMA DE PÓS-GRADUAÇÃO EM ADMINISTRAÇÃO UNIVERSITÁRIA DA UFSC PARA A REALIZAÇÃO DAS AÇÕES PREVISTAS EM SEU PLANEJAMENTO ESTRATÉGICO
}

Analysis of the Required Competences to Collegiate Members of the Posgraduate Program in University Administration at Ufsc to Carry Out the Expected Actions in Strategic Planning

Leonardo Borges da Silva Martins

E-mail: leonardo.bsm@ufsc.br Mestre em Administração Universitária - PPGAU/UFSC. http://orcid.org/0000-0001-9985-9138

Nicolas Rufino dos Santos

E-mail: nicolasrufino4@gmail.com Mestre em Administração Universitária - PPGAU/UFSC. https://orcid.org/0000-0001-9628-2599

Marcos B. L. Dalmau

E-mail: professordalmau@gmail.com Dr. Professor - PPGAU e PPGA/UFSC. https://orcid.org/0000-0002-8620-1625 


\section{RESUMO}

Este estudo objetiva identificar as competências necessárias dos membros do Colegiado Pleno do Programa de Pós-Graduação em Administração Universitária da UFSC para a realização das ações previstas em seu planejamento estratégico. $O$ trabalho se justifica pela necessidade de aprofundamento dos estudos sobre Gestão por Competências no campo das universidades, ao buscar avançar nas discussões sobre o tema e desenvolver novas implicações no que diz respeito às competências necessárias de membros de colegiado em programas de pós-graduação. Buscou-se identificar as ações previstas no planejamento estratégico do PPGAU/UFSC; definir as competências previstas no planejamento estratégico do Programa; mapear as competências dos membros de seu Colegiado Pleno e sugerir ações de encaminhamento para os gestores e membros envolvidos nas ações estratégicas. Quanto à metodologia, trata-se de uma pesquisa de abordagem qualitativa, estudo de caso, com pesquisas bibliográfica e documental, sendo utilizadas entrevista e análise de conteúdo. Os resultados da pesquisa evidenciam uma quantidade considerável de competências que foram apontadas e validadas pelos entrevistados e pela Coordenação do PPGAU/UFSC, o que indica a minuciosidade das ações do serviço público e a seleção dos indivíduos mais adequados para executar as ações que culminam nos objetivos do planejamento estratégico. As conclusões sugerem a gestão por competências como requisito fundamental para o atingimento da excelência no âmbito das instituições universitárias e que contribuições científicas são indispensáveis aos gestores acadêmicos para ampliar o leque de ferramentas disponíveis para o exercício profissionalizado no cotidiano da gestão universitária.

Palavras-chave: Gestão universitária, Gestão por competências, Mapeamento de competências, Planejamento estratégico.

\section{ABSTRACT}

This study aims to identify the necessary competences of the members of the Collegiate of the Program in University Administration at UFSC to carry out the actions foreseen in its strategic planning. The work is justified by the need to deepen studies on Management by Competencies in the field of universities, seeking to advance discussions on the subject and develop new implications with regard to the necessary competencies of collegiate members in graduate programs. We sought to identify the actions foreseen in the strategic planning of the PPGAU/UFSC; define the competencies foreseen in the Program's strategic planning; map the competences of the members of its Full Collegiate and suggest referral actions for managers and members involved in strategic actions. As for the methodology, it is a research with a qualitative approach, a case study, with bibliographical and documental research, being used interviews and content analysis. The survey results show a considerable amount of skills that were identified and validated by the interviewees and by the PPGAU/ UFSC Coordination, which indicates the thoroughness of public service actions and the selection of the most suitable individuals to perform the actions that culminate in the objectives of strategic planning. The conclusions suggest that competency management is a fundamental requirement for achieving excellence within university institutions and that scientific contributions are indispensable for academic managers to expand the range of tools available for professional practice in the daily routine of university management.

Keywords: University management, Competence management, Competence mapping, Strategic planning. 


\section{INTRODUÇÃO}

A complexidade das organizações, em especial das universidades, assim como a alta produtividade e a globalização demandam dos gestores um conjunto de competências para lidar com impasses e buscar estratégias organizacionais. Permitir que as organizações sobrevivam às mudanças e inovações do dia a dia significa reconhecer a necessidade de dispor de pessoas que possuam competências específicas para lidar com essa realidade e trabalhem pelo aperfeiçoamento do ambiente.

No contexto das grandes transformações no mundo do trabalho, faz-se necessária a formação de trabalhadores com perfil multifuncional, com habilidades e atitudes compatíveis com os postos a serem ocupados. Dessa forma, não é mais aceitável que o trabalhador disponha exclusivamente de conhecimentos técnicos para o desempenho de suas funções.

Fleury \& Fleury (2001) constatam que a competitividade e a globalização levaram ao alinhamento definitivo das políticas de gestão de recursos humanos às estratégias empresariais, incorporando à prática organizacional o conceito de competência como base do modelo para se conduzir as pessoas. Essa afirmação traduz a concepção de que atualmente é necessário que as organizações utilizem modelos de gestão por competências na busca da sobrevivência e atingimento da excelência. E se tal afirmação se aplica no âmbito das organizações, também resulta no campo das universidades.

Para Rios Neto (2016) a universidade é portadora de objetivos, sistemas hierárquicos e estruturas diferenciadas de outras organizações. É inevitável a existência de contradições, ambiguidades e conflitos, os quais são também fontes de aprendizado, criatividade e inovação.

O Programa de Pós-Graduação em Administração Universitária da Universidade Federal de Santa Catarina (PPGAU/UFSC) iniciou suas atividades no ano de 2010. A oferta do curso de Mestrado Profissional em Administração Universitária tem como principal objetivo "formar profissionais altamente qualificados, capazes de construir novos conhecimentos e práticas em administração universitária para o desenvolvimento institucional" (Universidade Federal de Santa Catarina [UFSC], 2019).

Conforme define o Regimento do PPGAU/UFSC: "a coordenação didática do Programa de Pós-Graduação em Administração Universitária caberá aos seguintes órgãos colegiados: I - Colegiado Pleno; II - Colegiado Delegado" (UFSC, 2017, p. 2). Os órgãos colegiados são os órgãos deliberativos, formados pelos membros que possuem a autoridade para decidir após consulta e reflexão. Por sua vez, os órgãos deliberativos demandam, de seus membros, conhecimentos, habilidades e atitudes específicas no processo decisório, pois as decisões tomadas são representativas e definem políticas e diretrizes para todos o contexto do Programa. 
Diante desse breve contexto, pergunta-se: quais competências são necessárias aos membros do colegiado pleno do Programa de Pós-Graduação em Administração Universitária para a realização das ações previstas em seu planejamento estratégico?

Portanto, o objetivo do artigo se constitui em identificar quais competências são necessárias aos membros do Colegiado Pleno do Programa de Pós-Graduação em Administração Universitária da Universidade Federal de Santa Catarina para a realização das ações previstas em seu planejamento estratégico, uma vez que sem essas, torna-se dificultoso colocar em prática todas as ações estratégicas delineadas, o que pode acarretar em prejuízos em termos de tempo e de recursos das mais variadas naturezas.

O objetivo deste trabalho se desdobra em etapas específicas, que são: a) identificar as ações previstas no planejamento estratégico do Programa de Pós-Graduação em Administração Universitária; b) definir/estratificar as competências previstas no planejamento estratégico do Programa de Pós-Graduação em Administração Universitária; c) mapear as competências dos membros do Colegiado Pleno do Programa de Pós-Graduação em Administração Universitária; d) sugerir ações de encaminhamento pós conclusão desta primeira etapa do mapeamento para os gestores e membros envolvidos nas ações estratégicas do Programa de Pós-Graduação em Administração Universitária com base nas competências mapeadas.

Este estudo se justifica a partir da necessidade de aprofundamento dos estudos sobre Gestão por Competências no campo das universidades, pois tanto busca avançar na discussão sobre o tema no âmbito dessas organizações quanto em desenvolver novas implicações no que diz respeito às competências necessárias de membros de colegiado em programas de pós-graduação de diversas instituições de ensino superior. Trata-se de um pretexto fundamental, pois tanto as universidades são instituições que apresentam conflitos e ambiguidades (Rios Neto, 2016), quanto o estudo possui uma aplicabilidade dos estudos de Gestão por Competência no campo dessas instituições.

\section{FUNDAMENTAÇÃO TEÓRICA}

Neste capítulo, serão evidenciados os conceitos considerados norteadores para a consecução do trabalho.

\subsection{COMPETÊNCIA: UM CONCEITO, DIFERENTES CONCEPÇÕES}

Assim como diversos conceitos desenvolvidos no campo da administração, a competência foi objeto de diversos entendimentos ao longo da história. A partir da segunda metade do século XIII, a competência era compreendida simplesmente como um código 
jurídico que designava um indivíduo ou instituição capaz de avaliar e julgar determinadas matérias (Escola Nacional de Administração Pública [ENAP], 2005). Com o advento da Administração Científica, no qual se preocupava com as matérias como a racionalidade e a profissionalização nas organizações, a noção de Competência adquiriu nova dimensão, passando a ser associada como a capacidade de um indivíduo em desempenhar um dado trabalho (Isambert-Jamati, 1997 como citado em ENAP, 2005).

Por consequência do progresso e do aprofundamento da complexidade no âmbito das relações de trabalho, e em função de demandas por mais profissionalização no campo da gestão pública, passou-se a considerar a competência não só como um conjunto de conhecimentos, mas como determinadas habilidades interpessoais e sociais (ENAP, 2005). Para McClelland (1973), a competência consiste em características observáveis de um indivíduo - conhecimentos, habilidades, objetivos e valores - que são capazes de promover um desempenho factível no trabalho e na vida cotidiana do indivíduo.

Sparrow \& Bognanno (1994) definem competência como sucessivos comportamentos denominados notáveis para o atingimento de um desempenho satisfatório tanto no ambiente de trabalho, como na carreira profissional como um todo, ou até mesmo na estratégia organizacional. Outros autores, como Zarifian (2001), sustentam que competência traduz no ato de assumir responsabilidades diante das mais complexas situações, como também na capacidade reflexiva de atuar sobre o trabalho, de modo a permitir que o profissional lide com ocasiões inesperadas e inusitadas.

Para Fleury \& Fleury (2001), a competência surge a partir da associação de verbos e expressões, tais como: saber, agir, mobilizar recursos, aprender, saber se engajar, etc. Tratase, portanto, não apenas de um conjunto de conhecimentos, mas também de habilidades em funcionamento na dinâmica organizacional.

Madruga (2018), em sua obra sobre treinamento e desenvolvimento, defende um significado ampliado de competências: conhecimentos, habilidades, atitudes e resultados. Consoante o autor, é necessário tanto dirigir as ações educacionais com foco em resultados quanto incluir resultados para garantir que seja orientado para o êxito. $O$ autor alega que para considerar que alguém adquiriu uma competência é preciso o domínio do saber, do fazer e se movimente com atitude para implantar o que está definido, mas sempre orientado para o resultado de forma a trazer mais benefícios para si e para os outros.

A Escola Nacional de Administração Pública (ENAP) elenca determinados elementos comuns embutidos em diversos conceitos de competência. São eles: i) trabalho; ii) os conhecimentos, habilidades e atitudes; iii) imprevisibilidade e subjetividade.

A ENAP (2020) elaborou um processo seletivo para Coordenador-Geral de PósGraduação Strictu Sensu Neste processo há a identificação das competências do Coordenador. Dentre elas destacam-se: capacidade de gestão, negociação, comunicação, orientação para 
resultados, gestão de conflitos, orientação por valores éticos e visão sistêmica. Importante destacar as características dessas competências para verificar compatibilidade com competências indicadas pelos entrevistados deste estudo.

Para Fleury \& Fleury (2001), uma organização determina sua competitividade a partir da dinâmica entre competências organizacionais e estratégia competitiva. Para eles, uma nova estratégia implementada constitui uma nova composição dos recursos e competências e que, ciclicamente, irão influenciar na formulação de uma nova estratégia, conforme ilustrado na Figura 1.

Figura 1

Ciclo das competências

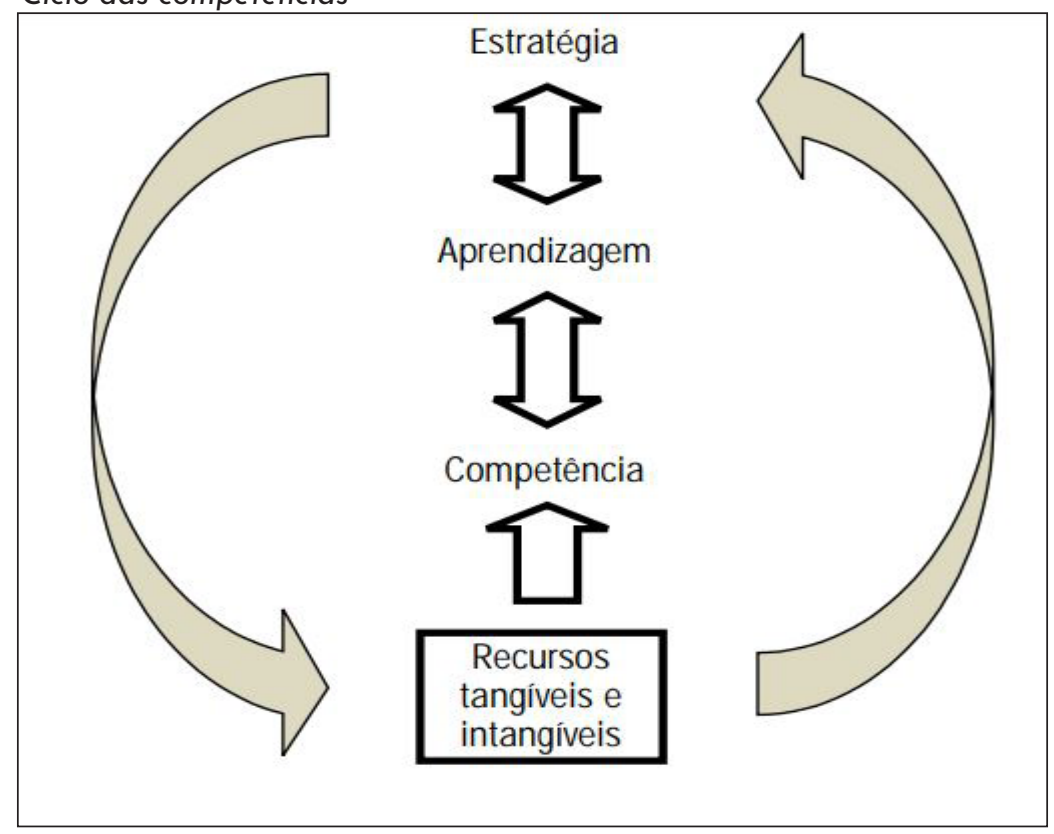

Fonte: Fleury e Fleury (2001).

Com a finalidade de desenvolver uma tipologia capaz de firmar e relacionar a formulação de estratégias com o desenvolvimento de competências, Fleury \& Fleury (2001), classificam as competências essenciais em três grandes áreas: i) operações; ii) produtos/ serviços; iii) vendas/marketing. Por outro lado, existem um conjunto de demais funções que não são essenciais no âmbito das organizações, denominadas de apoio, para os mesmos autores: i) finanças; ii) tecnologia de informação; iii) gestão de recursos humanos.

\subsection{A EXIGÊNCIA DE MECANISMOS DE GESTÃO POR COMPETÊNCIAS NO ÂMBITO DAS ORGANIZAÇÕES PÚBLICAS}

A Gestão de Pessoas por Competências está situada em uma importante posição do debate nacional na contemporaneidade em função de sua interação direta para com a 
melhoria da gestão organizacional. As mudanças vivenciadas pelo setor público nas últimas décadas acentuaram a necessidade da incorporação da Gestão por Competências na esfera pública, no sentido de repensar a dinâmica de atuação do Estado para atender distintas demandas da sociedade em contextos diferentes (ENAP, 2009).

Percebe-se a necessidade dos órgãos governamentais de se adaptarem às mudanças internacionais, não apenas no sentido de aperfeiçoarem suas ferramentas de gestão, como também de repensarem em formas de preparação dos trabalhadores para um ambiente cada vez mais complexo e exigente. Nesse sentido, a Gestão por Competências é encarada pelo setor público como uma nova perspectiva para desenvolver novas qualificações para o trabalho (ENAP, 2009).

O Decreto n 9.991/2019 dispõe sobre a Política Nacional de Desenvolvimento de Pessoas da administração pública federal direta, autárquica e fundacional e instiga uma nova etapa sobre o tema de Gestão por Competências, com a finalidade de promover o desenvolvimento dos servidores públicos nas competências exigidas na execução dos serviços públicos.

Dentre os objetivos do Plano de Desenvolvimento de Pessoas, estão: i) alinhar as ações de desenvolvimento e a estratégia do órgão ou da entidade; ii) estabelecer objetivos e metas institucionais como referência para o planejamento das ações de desenvolvimento; iii) atender às necessidades administrativas operacionais, táticas e estratégicas, vigentes e futuras.

De acordo com o decreto, o Plano de Desenvolvimento de Pessoas (PDP) deverá ser precedida por um Diagnóstico de Competências. Entende-se, por Diagnóstico de Competências, para os fins deste decreto, como a "identificação do conjunto de conhecimentos, habilidades e condutas necessários ao exercício do cargo ou da função" ( $\$ 3^{\circ}$ do Art. $3^{\circ}$ ). É possível perceber, portanto, que o referido decreto situa a Gestão por Competências no centro do desenvolvimento do plano de gestão por pessoas no âmbito dos órgãos governamentais.

\subsection{MAPEAMENTO DE COMPETÊNCIAS: DEFINIÇÃO, MÉTODO, E AÇÕES}

Segundo Brandão \& Bahry (2005), o alcance da eficiência e eficácia dependem gradativamente da capacidade das organizações em desenvolverem competências e compôlas ao redor de seus objetivos. O setor público deve tanto acompanhar esse movimento quanto adotar a gestão por competências como alternativa de gestão flexível, possibilitando o aperfeiçoamento na qualidade e eficiência dos serviços no campo da gestão pública.

O mapeamento de competências, de acordo com lenaga (1998), busca identificar as discrepâncias entre as competências necessárias para concretizar a estratégia da organização e as competências internas já existentes. 
A primeira etapa do mapeamento de competências consiste em identificar o conjunto de competências necessárias à consecução dos objetivos da organização por meio de uma prévia pesquisa documental com análise do conteúdo da missão, visão, objetivos e outros documentos do planejamento estratégico para, posteriormente, coletar dados com pessoaschave para a validação (Brandão \& Bahry, 2012; Bruno-Faria \& Brandão, 2003; Carbone et al., 2005).

Brandão \& Bahry (2012) sustentam que a descrição de uma competência deve representar um desempenho ou comportamento esperado, e que seja capaz de indicar o que o profissional deve ser capaz de fazer. Os autores ainda sugerem que na descrição das competências deve-se evitar descrições muito longas ou utilização de termos técnicos, ambiguidades, irrelevâncias e obviedades, duplicidades, abstrações e verbos que não expressem uma ação concreta, e que não seja passível de observação no trabalho.

Bruno-Faria \& Brandão (2003) sugerem que sejam utilizados tanto verbos que expressam ações concretas quanto que representam comportamentos observáveis no trabalho. Além disso, deve-se submeter tais descrições à avaliação de pessoas-chave da organização para a validação das competências descritas, visando garantir a compreensão do comportamento descrito.

É recomendável gravar os depoimentos dos entrevistados e registrar notas que facilitem a compreensão das respostas, como sugerem Richardson et al. (1999). Após as entrevistas realizadas, elas devem ser transcritas e analisadas, buscando identificar e descrever de forma objetiva as competências citadas como relevantes. Na análise do conteúdo das entrevistas, deve-se interpretar o discurso do entrevistado. Outro fator importante é a frequência com que cada competência é mencionada nas entrevistas, pois o número de menções indica a sua relevância, como sugere Brandão et al. (2002).

Além de identificar as competências necessárias inerentes à estratégia organizacional, o mapeamento de competências pressupõe inventariar as competências internas já disponíveis na organização, para identificar a lacuna entre competências requeridas e as já existentes (Carbone et al., 2005).

Brandão \& Bahry (2005) confirmam que, após realizado o mapeamento da lacuna de competências, é possível planejar e realizar a captação e desenvolvimento de competências profissionais, buscando otimizar a lacuna e retribuindo os profissionais que manifestam as competências necessárias à consecução dos objetivos organizacionais.

O conceito de competência utilizado neste trabalho se desdobra em determinadas dimensões: i) conhecimentos; ii) habilidades; iii) atitudes. 


\section{METODOLOGIA}

Esta pesquisa se caracterizou pela abordagem qualitativa, dado que, com base na caracterização de Richardson (1999) e Vergara (2014), houve esforço dos pesquisadores em compreender a essência e os significados de um fenômeno social, além de ser desprovido de um objeto estatístico para analisar o problema. $O$ estudo também se constituiu como de natureza aplicada, pois, de acordo com Vergara (2014), esse tipo de pesquisa tem o propósito de produzir conhecimento para aplicação de solução de problemas específicos, baseando-se em referenciais teóricos.

Quanto aos seus fins, esta pesquisa teve momentos de caráter descritivo explicativo. No que tange aos seus meios, tratou-se de um estudo de caso, de natureza qualitativa e descritiva, tendo como fonte direta de informações o ambiente onde ocorreu o fenômeno estudado, no caso, o PPGAU/UFSC. Também constituiu-se em uma pesquisa de campo, bibliográfica e documental, partindo do pressuposto da existência da necessidade de se abordar os diversos sujeitos do estudo para a devida compreensão do fenômeno, bem como em função do embasamento teórico e documental pertinente no esclarecimento dos fatos investigados.

Em relação aos sujeitos da pesquisa, foram definidos os membros do Colegiado Pleno do PPGAU/UFSC, totalizando 24 pessoas. A escolha se justificou devido ao fato de os membros serem atores envolvidos nas ações identificadas no planejamento estratégico do Programa. Para conhecimento, o Colegiado Pleno é a representação total de docentes, além de um percentual de alunos e servidores técnico-administrativos em educação que tem como incumbência definir o futuro do aludido Programa de Pós-Graduação. Já o Colegiado Delegado pode ser compreendido como a micro representação do Pleno, cujas pessoas foram eleitas pelos pares, tendo como atribuições a estruturação e operacionalização das propostas/idéias/ações para que o Colegiado principal (pleno) possa tomar as melhores decisões e fazer as devidas votações nas reuniões ordinárias.

Diante do exposto, para a realização deste trabalho foram escolhidas as pessoas pertencentes ao Colegiado Delegado - 5 (3 docentes, 1 servidor técnico administrativo e 1 representante discente, uma vez que o outro é um dos autores deste trabalho), além do ex-coordenador, totalizando, assim, 6 pessoas. A escolha levou em consideração o fato de trabalharem diretamente com as ações administrativas inerentes ao Colegiado Pleno, bem como pelo fato de ocuparem ou terem ocupado cargos de gestão em períodos pretéritos/ atual, o qual permitiu não apenas o conhecimento global dos atos existentes, mas, também, para que pudessem contextualizar e explicar os motivos de determinados fenômenos terem ocorrido. Nesse sentido, a pesquisa se deu por intermédio de entrevistas semiestruturadas 
aplicadas aos membros do Colegiado Delegado do PPGAU/UFSC, que aconteceram no período de setembro a dezembro de 2019.

No intuito de possibilitar maior clareza quanto aos procedimentos utilizados, explicase que na coleta de dados visando o atingimento do objetivo específico A (identificar as ações previstas no planejamento estratégico do Programa de Pós-Graduação em Administração Universitária), foram realizadas as pesquisas bibliográfica, documental e entrevista semiestruturada. Neste caso, partiu-se primeiramente da análise de documentos do referido programa referente ao Planejamento Estratégico realizado. A partir do mesmo, tomou-se ciência do conteúdo do plano, sendo que nos momentos em que houveram dúvidas a respeito da operacionalização ou do contexto de aplicação das estratégias, procurou-se saná-las mediante realização de entrevistas com membros do Colegiado Delegado.

Para a coleta de dados do objetivo específico B (definir/estratificar as competências previstas no planejamento estratégico do Programa de Pós-Graduação em Administração Universitária), também fez-se uso da pesquisa documental. Para tanto, analisou-se apenas os objetivos e estratégias que estavam em vigor durante a elaboração deste trabalho. Já os que não estavam no momento da coleta de dados foram excluídos por se entender que - mapeamento e diagnóstico das competências deve servir para ações futuras. Portanto, de 16 objetivos existentes no documento original, retirou-se 5, permanecendo, assim, 11 em andamento.

Para o atingimento do objetivo específico C (mapear as competências dos membros do Colegiado Pleno do Programa de Pós-Graduação em Administração Universitária), foram realizadas entrevistas semiestruturadas com os membros do Colegiado Delegado para identificar e mapear as competências consideradas adequadas para os membros do Colegiado Pleno. Para garantir condições de anonimato, estimou-se trabalhar com a identificação dos mesmos mediante nomeação "entrevistado 1", "entrevistado 2" e assim sucessivamente. Destaca-se que não foram selecionadas pessoas pertencentes ao referido Colegiado pela dificuldade de se estabelecer uma agenda comum para a realização das entrevistas, uma vez que elas ocorreram entre os meses de setembro e dezembro de 2019, ou seja, praticamente no final do semestre, o que se tornou um obstáculo considerável. No total foram 5 horas e 30 minutos despendidos nas entrevistas do estudo e a transcrição das entrevistas resultou em 13 páginas escritas.

De qualquer forma, o importante é que a realização das entrevistas ocorreu, o que vai ao encontro do ponderado por Brandão \& Bahry (2005), uma vez que para eles a entrevista constitui uma técnica de pesquisa bastante aplicada ao mapeamento de competências. Os autores citados entendem que esta técnica costuma ser utilizada para aferir as percepções dos entrevistados com os dados apurados na análise documental, buscando identificar as competências relevantes à organização. Foi exatamente isso que ocorreu. Ou seja: foi possível 
identificar os Conhecimentos, Habilidades e Atitudes que cada entrevistado considerava essencial para a consecução de cada um dos objetivos indicados no Planejamento Estratégico.

Dando continuidade, evidencia-se que para a descrição das competências utilizouse dos conceitos de Bruno-Faria \& Brandão (2003), no qual sugerem que sejam utilizados verbos que expressam ações concretas que representam comportamentos observáveis no trabalho. A única etapa que não foi possível concluir foi o da validação das competências descritas, explicado nas limitações deste estudo.

As ações sugeridas para o alinhamento proposto pelo objetivo específico $D$ (sugerir ações de encaminhamento pós conclusão desta primeira etapa do mapeamento para os gestores e membros envolvidos nas ações estratégicas do Programa de Pós-Graduação em Administração Universitária com base nas competências mapeadas) foram definidas após a coleta e análise dos dados por meio de estudo dirigido.

No que se refere às técnicas de análise dos dados, procurou-se utilizar o método da análise de conteúdo das falas obtidas por meio das entrevistas. Após a gravação das mesmas, transcreveu-se tudo o que foi falado pelos entrevistados para que, posteriormente, pudessem ser verificadas possíveis inconsistências ou falta de informações contextualizadas para se entender os fenômenos e características afirmadas. Deve-se destacar que, como as entrevistas foram extensas e com vários detalhes, não se encontou possíveis lacunas que fizessem com que os pesquisadores tivessem dúvidas ou incompreensões do que fora obtido em termos de informações. Além disso, procurou-se trabalhar a interpretação das respostas por intermédio da triangulação entre os conceitos oriundos da Fundamentação Teórica, as falas dos respondentes e o que estava escrito no documento norteador, no caso, o Plano Estratégico.

Por fim, deve-se ponderar sobre as limitações do estudo. Em função da pandemia do novo coronavírus (Covid-19) que assola o mundo, determinou-se para este trabalho a conclusão do mapeamento proposto pelos membros do Colegiado Delegado. Afirma-se que os pesquisadores têm total conhecimento que posteriormente deverão ser feitas entrevistas para validar as competências junto a atual Coordenação do Programa no período, assim como, para todos os membros do Colegiado Pleno.

Outra limitação encontra-se em relação ao período/mandato dos respondentes desta pesquisa, que, em alguns casos, se expirará em maio de 2020, podendo ou não serem reconduzidos. Logo, evidencia-se que este trabalho se baseou na composição do Colegiado Delegado vigente durante o segundo semestre de 2019. 


\section{APRESENTAÇÃO DO CASO}

O Programa de Pós-Graduação em Administração Universitária da Universidade Federal de Santa Catarina (PPGAU/UFSC) teve início com a aprovação da CAPES em 2009, apesar de já ser possível identificar visíveis esforços anteriores da instituição no sentido de aprofundar os estudos no campo da Gestão Universitária. Por se envolver no desenvolvimento de conhecimentos desta área desde a década de 1960 - com a organização de seminários, de Núcleo de Pesquisas e Estudos em Administração Universitária, bem como na oferta de cursos de especialização na área de Gestão Universitária - a Universidade Federal de Santa Catarina se constitui como uma instituição precursora nos estudos na referida área.

Alcançando o conceito 4 pela avaliação periódica da Coordenação de Aperfeiçoamento de Pessoal de Nível Superior do Ministério da Educação (CAPES/MEC), o PPGAU/UFSC se constitui como um Programa de Pós-Graduação com visibilidade dentro da Universidade Federal de Santa Catarina, bem como do país como um todo, em função de seus trabalhos científicos dotarem da capacidade de aperfeiçoar os mecanismos das instituições universitárias de diferentes maneiras. Cabe esclarecer que a Coordenação do PPGAU/UFSC autorizou a execução deste estudo, além de colaborar com a coleta de dados.

Aprovado no dia 24 de maio de 2019, o Planejamento Estratégico (PE) do PPGAU/ UFSC tem o intuito de ampliar e acompanhar as ações estratégicas do Programa por parte dos seus principais interessados. A finalidade do planejamento estratégico vai ao encontro da visão do Programa, que consiste em "ser referência na produção e na transferência de conhecimento científico e tecnológico aplicado à administração universitária" (UFSC, 2019, p. 2). Além do mais, de acordo com o Planejamento Estratégico do PPGAU/UFSC, o Programa tem o objetivo de "formar profissionais capazes de construir conhecimentos práticos em administração universitária, para o desenvolvimento das instituições de educação superior" (UFSC, 2019, p. 1).

De acordo com o documento do Planejamento Estratégico do PPGAU/UFSC, cada ação estratégica pode ser proposta por quatro agentes: i) coordenação; ii) secretaria; iii) docentes; iv) representantes discentes. Além disso, cada uma delas deve conter as seguintes informações: i) breve descrição e objetivos; ii) horas estimadas para a execução; iii) prazo estimado de conclusão; iv) equipe mínima necessária. Este tipo de estruturação é importante, pois permite a todos os membros do Programa uma noção real do que deverá ser feito. Diante do exposto, o Quadro 1 sintetiza as informações sobre a Metodologia do Planejamento Estratégico do PPGAU/UFSC: 
Quadro 1

Metodologia do Planejamento Estratégico do PPGAU/UFSC

\begin{tabular}{ccc}
\hline $\begin{array}{c}\text { Atores que podem propor } \\
\text { ações estratégicas }\end{array}$ & $\begin{array}{c}\text { Informações requeridas para pro- } \\
\text { por uma ação estratégica }\end{array}$ & $\begin{array}{c}\text { Critérios de avaliação da ação estra- } \\
\text { tégica }\end{array}$ \\
\hline Coordenação & Breve descrição e objetivos & $\begin{array}{c}\text { Potencial de contribuição para o cum- } \\
\text { primento da missão do Programa }\end{array}$ \\
\hline Secretaria & Horas estimadas para a execução & $\begin{array}{c}\text { Potencial de contribuição para constru- } \\
\text { ção e aprimoramento dos valores do } \\
\text { Programa }\end{array}$ \\
\hline Docentes & Prazo estimado de conclusão & Grau de Urgência \\
\hline Representantes Discentes & Equipe mínima necessária & \\
\hline Fonte: Modelo adaptado do Planejamento Estratégico do PPGAU/UFSC (UFSC, 2019).
\end{tabular}

Em termos de gestão, o preenchimento do item IV do campo "Informações requeridas para propor uma ação estratégica" tende a ser mais complexo do que aparenta, uma vez que se não houver um conhecimento pleno das características de competências da equipe necessárias, no caso de qualquer membro do Colegiado Pleno, os idealizadores das ações poderão ter dificuldades em dimensionar e definir quem poderá contribuir para a consecução daquilo que está sendo proposto.

Já no que se refere à avaliação de cada ação estratégica, a metodologia do PE institui que o Colegiado Pleno irá avaliar cada ação quanto a: i) potencial de contribuição para o cumprimento da missão do Programa; ii) potencial de contribuição para construção e aprimoramento dos valores do Programa; iii) grau de urgência. Para tanto, conforme informações obtidas mediante análise documental, cada ação receberá uma avaliação dos membros do colegiado a partir de uma escala, que tem início do primeiro nível 1 - que representa "pouco potencial" ou "pouco urgente" - até 5 - que significa "muito potencial" ou "muito urgente". Após essa etapa, far-se-á uma soma da média de cada um dos três itens de avaliação. O PE institui ainda que o ator responsável pela ação, além de executar e coordenar a ação propriamente dita, deverá prestar as informações necessárias ao colegiado sobre o andamento da ação a partir do preenchimento de um relatório de execução.

A Resolução Normativa $n^{\circ}$ 095/Cun/2017, que aprova o Regimento Interno do Programa de Pós-Graduação em Administração Universitária da Universidade Federal de Santa Catarina (UFSC), explica, no Art. $3^{\circ}$, que a coordenação didática do Programa caberá ao Colegiado Pleno e ao Colegiado Delegado. Conforme mencionado no capítulo da metodologia, o Colegiado Delegado do Programa é composto a partir da seguinte estrutura, consoante a Resolução Normativa $n^{\circ}$ 095: i) coordenador, como presidente; b) subcoordenador, como sub-presidente, c) professores credenciados como permanentes no Programa; d) representantes do Corpo Discente, na proporção de 1/5 dos membros docentes do Colegiado Delegado, desprezada a fração. Já o Colegiado Delegado, de acordo com o Art. $7^{\circ}$ da resolução, será convocado pelo presidente e terá ao menos duas reuniões ordinárias anuais e reuniões extraordinárias. 
Ainda com base na análise documental, verifica-se que o Planejamento Estratégico do PPGAU/UFSC se desdobra em determinados objetivos estratégicos, que são classificados em: i) objetivos estratégicos contínuos; ii) objetivos estratégicos únicos. Os objetivos estratégicos contínuos, segundo o PE, são aqueles que requerem monitoramento e reedições constantes. Já os objetivos estratégicos únicos perseguem um resultado único, não havendo necessidade de reedições, como a instituição de uma nova resolução, por exemplo. O Quadro 02 demonstra os objetivos do Planejamento Estratégico do PPGAU/UFSC:

Quadro 2

Objetivos do Planejamento Estratégico do PPGAU/UFSC

\begin{tabular}{|c|c|c|c|c|c|}
\hline Código & Objetivo Geral & Objetivos Específicos & $\begin{array}{l}\text { Horas esti- } \\
\text { madas para } \\
\text { execução }\end{array}$ & $\begin{array}{l}\text { Prazo es- } \\
\text { timado de } \\
\text { conclusão }\end{array}$ & $\begin{array}{l}\text { Equipe } \\
\text { mínima }\end{array}$ \\
\hline COD-001 & $\begin{array}{l}\text { Semana de Inte- } \\
\text { gração PPGAU }\end{array}$ & - & 60 & Março & 01 \\
\hline COD-002 & $\begin{array}{c}\text { Processo Seletivo } \\
\text { Discente }\end{array}$ & - & 120 & Dezembro & 03 \\
\hline COD-003 & $\begin{array}{c}\text { Representação } \\
\text { Discente }\end{array}$ & - & 20 & Abril & 01 \\
\hline COD-0O4 & $\begin{array}{l}\text { Instituir no } \\
\text { Programa a } \\
\text { Regulamentação } \\
\text { para receber } \\
\text { Pós-Doutorandos } \\
\text { em Administração } \\
\text { Universitária }\end{array}$ & $\begin{array}{l}\text { A. Criar uma resolução que regu- } \\
\text { lamenta o estágio pós-doutoral no } \\
\text { Programa; } \\
\text { B. Lançar primeiro edital de ingresso } \\
\text { pós-doutoral; } \\
\text { C. Avaliar resolução e edital após } \\
\text { primeiro uso }\end{array}$ & 24 & $\begin{array}{l}\text { Março de } \\
2020\end{array}$ & 03 \\
\hline
\end{tabular}

A. Evidenciar para os participantes os desafios "da dissertação à implementação";

B. Divulgar em mídias sociais e site do Programa a atividade, para Instituir o Seminá- ficar documentado as conquistas COD-005 rio de Egressos do PPGAU derivadas da dissertação de nossos egressos;

C. Criar um espaço de compartiIhamento que sinalize o início do semestre, para integrar docentes, egressos e discentes das turmas em andamento.

\begin{tabular}{|c|c|c|c|c|c|}
\hline COD-006 & $\begin{array}{c}\text { Resolução de } \\
\text { Credenciamento e } \\
\text { Recredenciamento } \\
\text { de Docentes (Rea- } \\
\text { dequação) }\end{array}$ & $\begin{array}{l}\text { B. Dar transparência a todo o proces- } \\
\text { so de credenciamento e recredencia- } \\
\text { mento; } \\
\text { B. Dar a maior objetividade possí- } \\
\text { vel na avaliação dos candidatos a } \\
\text { docentes; } \\
\text { C. Almejar a melhoria contínua da } \\
\text { qualidade do programa; } \\
\text { D. Adequar os parâmetros de creden- } \\
\text { ciamento às diretrizes do SNPG. }\end{array}$ & 24 horas & $\begin{array}{c}\text { Junho de } \\
2019 .\end{array}$ & 02 \\
\hline COD-007 & $\begin{array}{c}\text { Instituir a Avalia- } \\
\text { ção da Secretaria } \\
\text { do PPGAU }\end{array}$ & & 40 horas. & $\begin{array}{l}\text { Dezembro } \\
\text { de } 2020 \text { e } \\
\text { Março de } \\
2021 \text { para } \\
\text { relatório }\end{array}$ & 01 \\
\hline
\end{tabular}




\begin{tabular}{|c|c|c|c|c|c|}
\hline Código & Objetivo Geral & Objetivos Específicos & $\begin{array}{l}\text { Horas esti- } \\
\text { madas para } \\
\text { execução }\end{array}$ & $\begin{array}{l}\text { Prazo es- } \\
\text { timado de } \\
\text { conclusão }\end{array}$ & $\begin{array}{l}\text { Equipe } \\
\text { mínima }\end{array}$ \\
\hline COD-008 & $\begin{array}{c}\text { Reestruturar Pla- } \\
\text { nos de Ensino }\end{array}$ & & 30 horas. & $\begin{array}{l}\text { Dezembro } \\
\text { de } 2020 .\end{array}$ & 02. \\
\hline COD-009 & $\begin{array}{l}\text { Instituir o Mo- } \\
\text { nitoramento da } \\
\text { Inserção Social }\end{array}$ & & 120 horas & $\begin{array}{l}\text { Dezembro } \\
\text { de } 2020\end{array}$ & 03. \\
\hline COD-010 & $\begin{array}{c}\text { Oferta de Turma } \\
\text { Fora de Sede - } \\
\text { UFMS }\end{array}$ & $\begin{array}{l}\text { A. Criar, estruturar e aprovar a pro- } \\
\text { posta de Turma Fora de Sede. } \\
\text { B. Ofertar a Turma Fora de Sede. } \\
\text { C. Avaliar o Atingimento do Escopo } \\
\text { do Projeto. }\end{array}$ & $\begin{array}{l}900 \text { horas } \\
\text { (100 de } \\
\text { coordena- } \\
\text { ção; } 400 \text { de } \\
\text { disciplinas; } \\
400 \text { de } \\
\text { orientação). }\end{array}$ & $\begin{array}{l}\text { Fevereiro } \\
\text { de } 2022 .\end{array}$ & 10 \\
\hline COD-011 & $\begin{array}{l}\text { Instituir a Avalia- } \\
\text { ção do Docente } \\
\text { pelo Discente }\end{array}$ & & 60 horas. & $\begin{array}{l}\text { Dezembro } \\
\text { de } 2020 .\end{array}$ & 03 \\
\hline COD-012 & $\begin{array}{c}\text { Criar Diretrizes } \\
\text { do Currículo do } \\
\text { Curso }\end{array}$ & & 60 horas. & $\begin{array}{l}\text { Dezembro } \\
\text { de } 2020 .\end{array}$ & 03 \\
\hline COD-013 & $\begin{array}{c}\text { Criar Proposta de } \\
\text { Doutorado }\end{array}$ & & 220 horas. & $\begin{array}{l}\text { Março de } \\
2020 .\end{array}$ & 06 \\
\hline COD-014 & $\begin{array}{c}\text { Criar Imersão } \\
\text { Profissional }\end{array}$ & & 60 horas. & $\begin{array}{l}\text { Agosto de } \\
2019 .\end{array}$ & 02 \\
\hline COD-015 & $\begin{array}{c}\text { Instituir o Plano } \\
\text { de Comunicação } \\
\text { Estratégica }\end{array}$ & & 24 horas. & $\begin{array}{c}\text { Junho de } \\
2021\end{array}$ & 02 \\
\hline COD-016 & $\begin{array}{c}\text { Instituir a Gestão } \\
\text { de Egressos }\end{array}$ & & 60 horas & $\begin{array}{l}\text { Junho de } \\
2020 .\end{array}$ & 03 \\
\hline
\end{tabular}

Fonte: Planejamento Estratégico do PPGAU/UFSC (UFSC, 2019).

Conforme já mencionado no capítulo da Metodologia, dos 16 objetivos existentes, alguns já foram cumpridos antes do início deste trabalho. Portanto, considerou-se apenas 11, cujas datas de término poderão auxiliar na interpretação dos que foram considerados para este trabalho. São eles: COD 001, COD 002, COD 005, COD 006, COD 014. Entretanto, os dois primeiros são realizados todos os anos.

\section{ANÁLISE E DISCUSSÃO}

A Gestão por Competências tende a proporcionar aos gestores institucionais ferramentas para que eles possam adequar suas ideias às pessoas que trabalham em seus domínios. No caso da Gestão Universitária, a Gestão por Competências oferece condições de alinhar o que foi planejado ao que será executado.

Atualmente é comum escutar críticas ao Planejamento Estratégico. Segundo Pereira (2010), isso ocorre porque muitas vezes os gestores não têm claramente definidos objetivos alcançáveis, assim como não têm noção evidente de como está constituído tecnicamente 
o seu corpo funcional para a consecução do que se propôs. Em outras palavras, acabase propondo algo que não se tem a devida competência para se desenvolver, o que cria desestímulos ao longo do tempo e preocupações futuras quanto a definição de outras ações e objetivos.

Tal contexto citado acima não é diferente no caso das preocupações referentes ao PPGAU. De acordo com informações oriundas das entrevistas realizadas com membros do Colegiado Delegado, o Entrevistado 1 (El) fez afirmações no sentido de demonstrar que há uma preocupação com a efetivação das ações propostas no Planejamento Estratégico. Segundo o entrevistado:

O que estamos percebendo é que será mais interessante no futuro que o programa meça, planeje e alcance o resultado em cima do que foi planejado, do que o resultado absoluto em si. Até então, os Programas são avaliados de forma absoluta 'teve $\mathrm{X}$ artigos publicados', e no futuro isso será relativizado. 'Eu vou ser avaliado pelo que medi, planejei e alcancei'. É uma tendência, e não será efetivado agora. Será uma tendência futura (El).

Ainda de acordo com o Entrevistado 1:

As ações estratégicas ganham e perdem relevância em função de alterações de cenário, como alterações de legislação da CAPES, ou cenário interno, como ter uma pessoa e perdê-la, ou surgir um convênio interessante. A ideia é manter um histórico do porquê tal ação foi cancelada, e não porque não quis fazer (El).

O que foi exposto pelo Entrevistado 1 mostra que o mapeamento de competências das ações do Programa constitui como uma ferramenta valiosa para a perpetuação do atingimento dos objetivos estratégicos, pois ela atuará diretamente, tanto na identificação das discrepâncias entre as competências necessárias para concretizar as estratégias organizacionais e as competências internas já existentes quanto em seu alinhamento. De certa forma, vai ao encontro do que foi descrito por Pereira (2010). Nota-se que o mapeamento de competências passará a ter um papel mais importante para o atingimento dos objetivos do Planejamento Estratégico do Programa, visto que a avaliação da CAPES tende a estar voltada justamente para o instrumento.

Nesse sentido, o primeiro passo foi o de mapear as características de competências consideradas referência para os membros do Colegiado Pleno. A título de exemplo, a primeira etapa foi realizada com cada um dos sujeitos e buscava o preenchimento da planilha da seguinte forma: 
Quadro 3

Planilha exemplo Objetivos $x$ CHA para preenchimento com os respondentes

\begin{tabular}{|c|c|c|c|c|}
\hline $\begin{array}{l}\text { Objetivos do Planeja- } \\
\text { mento Estratégico }\end{array}$ & Subações & Conhecimentos & Habilidades & Atitudes \\
\hline \multirow{3}{*}{$\begin{array}{c}\text { 4- Instituir no Pro- } \\
\text { grama a Regulamen- } \\
\text { tação para receber } \\
\text { Pós-Doutorandos em } \\
\text { Administração Univer- } \\
\text { sitária }\end{array}$} & $\begin{array}{l}\text { A. Criar uma resolução } \\
\text { que regulamenta o } \\
\text { estágio pós-doutoral } \\
\text { no Programa; }\end{array}$ & $\begin{array}{c}\text { - Resolução } 36 \\
\text { - Como escrever uma } \\
\text { resolução } \\
\text { - Gestão de processos } \\
\text { - Interesses do programa } \\
\text { - Boas práticas do pro- } \\
\text { cesso seletivo conforme } \\
\text { órgãos de controle }\end{array}$ & $\begin{array}{l}\text { - Gestão do } \\
\text { tempo } \\
\text { - Analítica } \\
\text { - Lógica } \\
\text { - Comunicação } \\
\text { escrita }\end{array}$ & $\begin{array}{l}\text { - Paciência } \\
\text { - Comprometi- } \\
\text { mento } \\
\text { - Detalhismo } \\
\text { - Clareza }\end{array}$ \\
\hline & $\begin{array}{l}\text { B. Lançar primeiro } \\
\text { edital de ingresso pós- } \\
\text {-doutoral; }\end{array}$ & $\begin{array}{c}\text { - Publicização } \\
\text { - Técnicas } \\
\text { - Resolução criada } \\
\text { - Boas práticas no pro- } \\
\text { cesso seletivo } \\
\text { - Redação de editais } \\
\text { - Resolução } 36\end{array}$ & - Comunicação & $\begin{array}{l}\text { - Cumprimen- } \\
\text { to de prazos }\end{array}$ \\
\hline & $\begin{array}{c}\text { C. Avaliar resolução e } \\
\text { edital após primeiro } \\
\text { uso }\end{array}$ & $\begin{array}{c}\text { - Objetivos da resolução } \\
\text { e sua aplicação } \\
\text { - Avaliação (processo) } \\
\text { - Conhecer as lições } \\
\text { aprendidas do programa } \\
\text { - Ferramentas de ava- } \\
\text { liação }\end{array}$ & $\begin{array}{l}\text { - Comunicação } \\
\text { - Organizar } \\
\text { rotina } \\
\text { - Controle e } \\
\text { acompanha- } \\
\text { mento do } \\
\text { processo }\end{array}$ & $\begin{array}{l}\text { - Proatividade } \\
\text { - Cumprimen- } \\
\text { to de prazos } \\
\text { - Transparên- } \\
\text { cia } \\
\text { - Ser motiva- } \\
\text { dor }\end{array}$ \\
\hline
\end{tabular}

Fonte: Dados primários dos autores (2020).

Um detalhe importante é que nas entrevistas ficou evidente a dificuldade dos sujeitos em indicar Atitudes para os membros responsáveis pela consecução dos objetivos, o que diferencia a quantidade final de Atitudes mapeadas em comparação com os Conhecimentos e Habilidades. Ao investigar as causas de tal situação, observou-se que os respondentes não são da área da Psicologia, o que não possibilitaria, evidentemente, uma compreensão conceitual de base. Por outro lado, o fato da maioria ser da área da Administração não significou que haveria um domínio conceitual mais completo de algo que não necessariamente representava a própria área de atuação profissional, o que é normal. Entretanto, foi perceptível que todos sabiam o que era necessário. A dificuldade estava apenas na classificação do $\mathrm{CHA}$.

Durante a análise das entrevistas confirmou-se, também, que alguns entrevistados tiveram maior facilidade do que outros em expor as competências em termos de alinhamento e pertinência. Isso ocorreu, principalmente, com as pessoas que já tinham ocupado cargos de gestão e tinham experiência em participação de colegiados. Outrossim, pode-se afirmar que também tem ligação direta com seus perfis pessoais inerentes às habilidades de comunicação porque enquanto alguns verbalizaram bastante, outros tiveram mais dificuldade em expor suas ideias. Também foi perceptível a dificuldade, em alguns momentos, de identificar e separar as Habilidades e Atitudes, bem como dificuldade em mensurar as competências que os membros do Colegiado Pleno deveriam ter, mesmo sendo de conhecimento o objetivo em estudo do Planejamento Estratégico no momento da entrevista. 
Foi quase unânime entre os membros do colegiado entrevistados a necessidade de se obter na dimensão Conhecimento o domínio em legislações pertinentes aos objetivos. Isso demonstra a amarra existente na UFSC com a questão burocrática, indispensável para o funcionamento das organizações públicas brasileiras.

Na dimensão Conhecimento outros itens foram bastantes citados, como: conhecer - PPGAU, bem como sua proposta e estrutura, o perfil e as necessidades dos alunos e as políticas e avaliação da CAPES. Esses conhecimentos demonstram que é imprescindível para os envolvidos no atingimento dos objetivos estratégicos, que conheçam o ambiente de trabalho e as pessoas que estão envolvidas nos processos para garantir a boa execução e resultado do objetivo. As políticas e a avaliação da CAPES estão por trás de toda as ações dos Programas de Pós-Graduação, pois o órgão é o responsável pela regulação da pósgraduação no Brasil.

Na dimensão Habilidade foi observado que os entrevistados mencionaram com frequência a necessidade de habilidades de planejamento, gestão do tempo, comunicação oral e escrita, trabalho em equipe e visão do todo para o atingimento dos objetivos. Esses aspectos também se relacionam ao fato da Universidade ser uma organização pública, visto que é essencial para o atingimento de metas o planejamento de ações e a gestão do tempo para não extrapolar prazos. A comunicação oral e escrita também aparecem com repetição e estão relacionadas à necessidade constante dos servidores em redigir documentos oficiais e públicos, além de eventuais apresentações que necessitam de habilidades orais. $O$ trabalho em equipe e a visão do todo estão relacionadas ao fato de praticamente todos os objetivos e ações serem executadas em equipes e exigem uma visão holística da organização para que o trabalho esteja baseado nos planos em diferentes níveis.

$\mathrm{Na}$ dimensão Atitude a proatividade, o comprometimento, a iniciativa e a vontade aparecem com frequência como competências indicadas pelos entrevistados para o atingimento dos objetivos do Planejamento Estratégico. De forma geral, essas atitudes apontadas estão diretamente relacionadas à necessidade de os indivíduos responsáveis pelas ações serem responsivos e agirem com sentimento de pertencimento à organização em foco. É importante que haja engajamento e cooperação para o atingimento das metas e objetivos.

Após o preenchimento de todas as respostas dos entrevistados, pôde-se visualizar que algumas categorias por atividades continham o termo "não soube responder", e outras apresentavam repetições de determinadas características.

Importante destacar que algumas das competências indicadas pelos entrevistados são similares àquelas indicadas pelo processo seletivo da ENAP (2020): comunicação, gestão de conflitos e visão sistêmica. A Planilha Objetivos x $\mathrm{CHA}$ preenchida com os dados obtidos dos respondentes está no Apêndice $A$. $O$ exposto no Apêndice $A$ fez com que fosse 
necessário utilizar uma metodologia apresentada por Dalmau (2019), onde a aglutinação dos indicadores obedeceria os critérios de representatividade ou de complementariedade conforme o contexto de uso. Logo, no caso em tela, optou-se pelo critério de representatividade porque para se trabalhar com o de complementariedade ainda seria necessário desenvolver mais uma etapa que não era objetivo deste trabalho: a aglutinação de indicadores de competência nas macro competências. Por conseguinte, após a devida ponderação de todos os indicadores pôde-se finalizar a construção do quadro, que ficou da seguinte maneira.

\section{Quadro 4}

Levantamento de indicadores de competências necessários (continua)

\begin{tabular}{|c|c|c|c|}
\hline $\begin{array}{l}\text { Objetivos do Planeja- } \\
\text { mento Estratégico }\end{array}$ & Conhecimentos & Habilidades & Atitudes \\
\hline $\begin{array}{l}\text { 1- Semana de Inte- } \\
\text { gração PPGAU }\end{array}$ & $\begin{array}{l}\text { - Técnica } \\
\text { - Legislação } \\
\text { - Normas } \\
\text { - PPG e UFSC } \\
\text { - Organização de eventos } \\
\text { - Redes de contato } \\
\text { - Funcionamento do curso } \\
\text { - Perfil do aluno } \\
\text { - Perfil do egresso } \\
\text { - Cerimonial } \\
\text { - Lições aprendidas } \\
\text { - Necessidades do aluno } \\
\text { - Dúvidas do aluno } \\
\text { - Rotina } \\
\text { - Estrutura do PPGAU } \\
\text { - Funcionamento da pós-gra- } \\
\text { duação } \\
\text { - História do Programa } \\
\text { - Relação direta do Programa }\end{array}$ & $\begin{array}{l}\text { - Gestão do tempo } \\
\text { - Planejamento } \\
\text { - Trabalho em equipe } \\
\text { - Comunicação escrita } \\
\text { - Comunicação oral } \\
\text { - "Apagar incêndios" } \\
\text { - Redação oficial } \\
\text { - Acompanhamento do } \\
\text { processo } \\
\text { - Visão do todo } \\
\text { - Acolhimento } \\
\text { - Relacionamento } \\
\text { - Criatividade } \\
\text { - Familiaridade com organi- } \\
\text { zação de eventos } \\
\text { - Organização }\end{array}$ & $\begin{array}{l}\text { - Proatividade } \\
\text { - Acompanhar agen- } \\
\text { da de apresentações } \\
\text { - Comprometimento } \\
\text { - Querer fazer } \\
\text { - Iniciativa } \\
\text { - Ser motivador } \\
\text { - Decisão rápida } \\
\text { - Empatia } \\
\text { - Manter contato com } \\
\text { palestrantes } \\
\text { - Voz ativa }\end{array}$ \\
\hline $\begin{array}{l}\text { 2- Processo Seletivo } \\
\text { Discente }\end{array}$ & $\begin{array}{l}\text { - Legislação } \\
\text { - Dinâmica acadêmica } \\
\text { - Dinâmica pedagógica } \\
\text { - PPGAU } \\
\text { - Demandas do mercado } \\
\text { - Candidatos } \\
\text { - Razão de existir } \\
\text { - Estrutura do PPGAU } \\
\text { - Gestão universitária } \\
\text { - Técnica } \\
\text { - Perfil do candidato } \\
\text { - Proposta do Programa } \\
\text { - Currículo do curso } \\
\text { - Boas práticas do processo } \\
\text { seletivo } \\
\text { - Edital anterior } \\
\text { - Lições aprendidas } \\
\text { - Linhas de pesquisa } \\
\text { - Áreas de atuação dos do- } \\
\text { centes } \\
\text { - Conhecer sobre áreas da } \\
\text { Administração Universitária }\end{array}$ & $\begin{array}{l}\text { - Gestão do tempo } \\
\text { - Planejamento } \\
\text { - Comunicação escrita ade- } \\
\text { quada ao objetivo da ação } \\
\text { - Entrevista } \\
\text { - Acompanhamento } \\
\text { - Correção de projetos } \\
\text { - Avaliação } \\
\text { - Gestão do tempo } \\
\text { - Familiaridade } \\
\text { - Argumentação } \\
\text { - Percepção } \\
\text { - Sensibilidade } \\
\text { - Técnicas } \\
\text { - Identificar o perfil do } \\
\text { candidato } \\
\text { - Interpessoal } \\
\text { - Capacidade analítica } \\
\text { - Trabalho em equipe } \\
\text { - Organização }\end{array}$ & $\begin{array}{l}\text { - Comprometimento } \\
\text { - Ética } \\
\text { - Cumprimento de } \\
\text { prazos } \\
\text { - Transparência } \\
\text { - Disponibilidade } \\
\text { - Interesse } \\
\text { - Ânimo } \\
\text { - Paciência } \\
\text { - Transparência } \\
\text { - Agir com ética } \\
\text { - Impessoalidade } \\
\text { - Preocupação com a } \\
\text { equidade } \\
\text { - Saber se relacionar } \\
\text { - Imparcialidade } \\
\text { - Iniciativa } \\
\text { - Cumprimento do } \\
\text { edital }\end{array}$ \\
\hline
\end{tabular}




\begin{tabular}{|c|c|c|c|}
\hline $\begin{array}{l}\text { Objetivos do Planeja- } \\
\text { mento Estratégico }\end{array}$ & Conhecimentos & Habilidades & Atitudes \\
\hline $\begin{array}{l}\text { 3- Representação } \\
\text { Discente }\end{array}$ & $\begin{array}{l}\text { - Legislação } \\
\text { - Resolução e Regimento } \\
\text { - Redação de edital } \\
\text { - Processo anterior } \\
\text { - Burocracia } \\
\text { - Rotina } \\
\text { - Representação colegiada } \\
\text { - Como deve ocorrer }\end{array}$ & $\begin{array}{l}\text { - Comunicação escrita } \\
\text { - Comunicação oral } \\
\text { - Habilidade processual } \\
\text { - Planejamento } \\
\text { - Organização da seleção } \\
\text { - Divulgar } \\
\text { - Organização }\end{array}$ & $\begin{array}{l}\text { - Proatividade } \\
\text { - Cumprimento de } \\
\text { prazos } \\
\text { - Transparência } \\
\text { - Ser motivador } \\
\text { - Querer fazer } \\
\text { - Iniciativa }\end{array}$ \\
\hline $\begin{array}{l}\text { 4- Instituir no Pro- } \\
\text { grama a Regulamen- } \\
\text { tação para receber } \\
\text { Pós-Doutorandos } \\
\text { em Administração } \\
\text { Universitária }\end{array}$ & $\begin{array}{l}\text { - O funcionamento do Progra- } \\
\text { ma } \\
\text { - Perfil do candidato } \\
\text { - Perfil profissional do candi- } \\
\text { dato } \\
\text { - Legislação } \\
\text { - Diretrizes da Capes } \\
\text { - Gestão universitária } \\
\text { - Resolução } 36 \\
\text { - Como escrever uma resolução } \\
\text { - Gestão de processos } \\
\text { - Interesses do programa } \\
\text { - Boas práticas do processo } \\
\text { seletivo conforme órgãos de } \\
\text { controle } \\
\text { - Processos seletivos } \\
\text { - Publicização } \\
\text { - Técnicas } \\
\text { - Resolução criada } \\
\text { - Boas práticas no processo } \\
\text { seletivo } \\
\text { - Edital } \\
\text { - Objetivos da resolução e sua } \\
\text { aplicação } \\
\text { - Avaliação (processo) } \\
\text { - Conhecer as lições aprendi- } \\
\text { das do programa } \\
\text { - Ferramentas de avaliação }\end{array}$ & $\begin{array}{l}\text { - Organização } \\
\text { - Contexto do Programa } \\
\text { - Visão estratégica do Pro- } \\
\text { grama } \\
\text { - Visão holística do Progra- } \\
\text { ma } \\
\text { - Entrevista } \\
\text { - Seleção } \\
\text { - Gestão do tempo } \\
\text { - Analítica } \\
\text { - Lógica } \\
\text { - Trabalhar com legislações } \\
\text { - Detalhista } \\
\text { - Planejamento } \\
\text { - Comunicação } \\
\text { - Fazer gestão } \\
\text { - Controle e acompanha- } \\
\text { mento do processo }\end{array}$ & $\begin{array}{l}\text { - Paciência } \\
\text { - Comprometimento } \\
\text { - Detalhismo } \\
\text { - Clareza } \\
\text { - Vontade } \\
\text { - Proatividade } \\
\text { - Cumprimento de } \\
\text { prazos } \\
\text { - Transparência } \\
\text { - Ser motivador } \\
\text { - Iniciativa }\end{array}$ \\
\hline $\begin{array}{l}\text { 8- Reestruturar Pla- } \\
\text { nos de Ensino }\end{array}$ & $\begin{array}{l}\text { - Metodologias ativas } \\
\text { - Sobre plano de ensino (estru- } \\
\text { tura - elementos) } \\
\text { - Regulamento do Programa } \\
\text { - Disciplinas } \\
\text { - "Mundo externo" } \\
\text { - Área de conhecimento (47) } \\
\text { - Mercado } \\
\text { - Outras instituições } \\
\text { - Perspectivas } \\
\text { - Estrutura curricular atual } \\
\text { - Técnico } \\
\text { - Legislação } \\
\text { - Normas } \\
\text { - Conteúdo pedagógico das } \\
\text { disciplinas } \\
\text { - Conhecimento das respecti- } \\
\text { vas áreas }\end{array}$ & $\begin{array}{l}\text { - Gestão do tempo } \\
\text { - Ouvir } \\
\text { - Gestão de arquivos } \\
\text { - Revisão de texto } \\
\text { - Planejamento } \\
\text { - Comunicação } \\
\text { - Experiência com o tema } \\
\text { - Sugerir melhorias } \\
\text { - Identificar o perfil que se } \\
\text { deseja do egresso } \\
\text { - Visão sistêmica } \\
\text { - Lidar com professores } \\
\text { dentro de uma estrutura } \\
\text { complexa e diversa } \\
\text { - Organização }\end{array}$ & $\begin{array}{l}\text { - Ser colaborativo } \\
\text { - Empatia } \\
\text { - Paciência } \\
\text { - Comprometimento } \\
\text { - Ser motivador } \\
\text { - Ser líder } \\
\text { - Querer a melhoria } \\
\text { - Olhar para fora e } \\
\text { para o futuro } \\
\text { - Buscar professores } \\
\text { novos } \\
\text { - Ser inovador e em. } \\
\text { preendedor } \\
\text { - Iniciativa }\end{array}$ \\
\hline
\end{tabular}




\begin{tabular}{|c|c|c|c|}
\hline $\begin{array}{l}\text { Objetivos do Planeja- } \\
\text { mento Estratégico }\end{array}$ & Conhecimentos & Habilidades & Atitudes \\
\hline $\begin{array}{l}\text { 9- Instituir o Mo- } \\
\text { nitoramento da } \\
\text { Inserção Social }\end{array}$ & $\begin{array}{l}\text { - Compreender as diretrizes do } \\
\text { SNPG no impacto da socie- } \\
\text { dade } \\
\text { - Compreender a proposta do } \\
\text { programa (o que se espera } \\
\text { do impacto na sociedade do } \\
\text { PPGAU) } \\
\text { - Conhecer sobre inserção } \\
\text { social } \\
\text { - Indicadores da Capes } \\
\text { - Região } \\
\text { - O que foi feito pelos alunos } \\
\text { - Entendimento da aproxima- } \\
\text { ção da universidade com a } \\
\text { sociedade } \\
\text { - Do que se trata para a ava- } \\
\text { liação da Capes } \\
\text { - Outras instituições } \\
\text { - Outras realidades }\end{array}$ & $\begin{array}{l}\text { - Sistematizar todas as } \\
\text { informações } \\
\text { - Gestão do tempo } \\
\text { - Comunicação escrita } \\
\text { - "Vender o próprio peixe" } \\
\text { - Contato com inserção } \\
\text { social } \\
\text { - Contato com extensão } \\
\text { - Saber identificar até que } \\
\text { ponto há transferência para } \\
\text { a sociedade } \\
\text { - Conectividade } \\
\text { - Fazer pesquisa } \\
\text { - Planejamento } \\
\text { - Comunicação } \\
\text { - Olhar para fora } \\
\text { - Percepção } \\
\text { - "Minerar informações" } \\
\text { - Identificar critérios da } \\
\text { Capes } \\
\text { - Conceitual (conseguir } \\
\text { analisar, criar critérios e } \\
\text { indicadores) } \\
\text { - Bom relacionamento com } \\
\text { egressos } \\
\text { - Sensibilizar o aluno e } \\
\text { egresso }\end{array}$ & $\begin{array}{l}\text { - Presença nas mídias } \\
\text { - Comprometimento } \\
\text { - Querer o monitora- } \\
\text { mento } \\
\text { - Manter contato com } \\
\text { egressos } \\
\text { - Compartilhar infor- } \\
\text { mações } \\
\text { - Ser criativo } \\
\text { - Buscar contatos } \\
\text { externos } \\
\text { - Iniciativa }\end{array}$ \\
\hline $\begin{array}{l}\text { 11- Instituir a Ava- } \\
\text { liação do Docente } \\
\text { pelo Discente }\end{array}$ & $\begin{array}{l}\text { - Estratégias para viabilizar a } \\
\text { avaliação } \\
\text { - Estratégias de avaliação } \\
\text { - Técnico } \\
\text { - Critérios } \\
\text { - Indicadores } \\
\text { - Diretrizes do SNPG } \\
\text { - Proposta do programa } \\
\text { - Como escrever resoluçães } \\
\text { - Gestão de processos } \\
\text { - Conhecer o processo de } \\
\text { avaliação } \\
\text { - Legislação que trata de ava- } \\
\text { liação (interna e externa) } \\
\text { - Ferramenta de avaliação } \\
\text { - Ferramentas e instrumentos } \\
\text { para aplicar } \\
\text { - Resolução criada } \\
\text { - Estatística descritiva } \\
\text { - Metaavaliação } \\
\text { - Resultado da avaliação } \\
\text { - O que fazer com os dados }\end{array}$ & $\begin{array}{l}\text { - Visão do todo } \\
\text { - Convencimento dos docen- } \\
\text { tes e discentes da impor- } \\
\text { tância do instrumento } \\
\text { - Comunicação } \\
\text { - Sensibilidade } \\
\text { - Empatia } \\
\text { - Planejamento } \\
\text { - Gestão de pessoas } \\
\text { - Gestão de conflitos } \\
\text { - Auxiliar o professor } \\
\text { - Envolver os estudantes } \\
\text { - Encorajar os estudantes } \\
\text { - Gestão do tempo } \\
\text { - Analítica } \\
\text { - Lógica } \\
\text { - Compilar } \\
\text { - O que fazer com os dados }\end{array}$ & $\begin{array}{l}\text { - Proteção de dados } \\
\text { pessoais } \\
\text { - Procurar manter o } \\
\text { contato com docentes } \\
\text { e discentes } \\
\text { - Assessorar os pro- } \\
\text { fessores quando mau } \\
\text { avaliados } \\
\text { - Imparcialidade } \\
\text { - Agir com objetivi- } \\
\text { dade } \\
\text { - Agir com clareza } \\
\text { - Empatia } \\
\text { - Ser criativo } \\
\text { - Interesse no tema } \\
\text { - Vontade } \\
\text { - Cumprimento dos } \\
\text { prazos } \\
\text { - Comprometimento } \\
\text { - Detalhismo } \\
\text { - Clareza } \\
\text { - Proatividade }\end{array}$ \\
\hline
\end{tabular}




\begin{tabular}{|c|c|c|c|}
\hline $\begin{array}{l}\text { Objetivos do Planeja- } \\
\text { mento Estratégico }\end{array}$ & Conhecimentos & Habilidades & Atitudes \\
\hline $\begin{array}{l}\text { 12- Criar Diretrizes } \\
\text { do Currículo do } \\
\text { Curso }\end{array}$ & $\begin{array}{l}\text { - Metodologias ativas } \\
\text { - Diretrizes da SNPG } \\
\text { - Documentos da Área } \\
\text { - Legislações } \\
\text { - Proposta do curso } \\
\text { - Perfil do discente } \\
\text { - Perfil do egresso } \\
\text { - Áreas e linhas de pesquisa } \\
\text { - Regras da Capes } \\
\text { - Estrutura do Programa } \\
\text { - "Ponto de saturação" } \\
\text { - Avaliação da Capes } \\
\text { - Currículo do curso } \\
\text { - Perfil desejado do egresso do } \\
\text { Programa } \\
\text { - Técnico } \\
\text { - Legislação } \\
\text { - Contemporaneidade } \\
\text { - Diretrizes do curso } \\
\text { - Funcionamento PPGAU }\end{array}$ & $\begin{array}{l}\text { - Pesquisa e desenvolvimen- } \\
\text { to } \\
\text { - Gestão do tempo } \\
\text { - Planejamento } \\
\text { - Comunicação escrita } \\
\text { - Trabalho em equipe } \\
\text { - Analítica } \\
\text { - Visão do todo } \\
\text { - Ouvir } \\
\text { - Alinhar conhecimentos } \\
\text { para coesão } \\
\text { - Visão holística } \\
\text { - Visão linear } \\
\text { - Perceptiva } \\
\text { - "Não ferir egos" } \\
\text { - Convencimento } \\
\text { - Estabelecer diretrizes } \\
\text { - Capacidade analítica } \\
\text { - Ter familiaridade com as } \\
\text { diretrizes } \\
\text { - Organização }\end{array}$ & $\begin{array}{l}\text { - Empreender } \\
\text { - Comprometimento } \\
\text { - Paciência } \\
\text { - Clareza } \\
\text { - Proatividade } \\
\text { - Querer assimilar o } \\
\text { conhecimento } \\
\text { - Planejamento } \\
\text { - Ser inovador } \\
\text { - Ser criativo } \\
\text { - Iniciativa }\end{array}$ \\
\hline $\begin{array}{l}\text { 13- Criar Proposta } \\
\text { de Doutorado }\end{array}$ & $\begin{array}{l}\text { - Metodologias ativas } \\
\text { - Trâmite interno de criação de } \\
\text { curso novo } \\
\text { - Diretrizes do SNPG } \\
\text { - Documentos de Área } \\
\text { - Conhecer proposta do pro- } \\
\text { grama e o que significa } \\
\text { - Currículos das disciplinas } \\
\text { - Lógica da constituição do } \\
\text { currículo } \\
\text { - Conhecer todas as resoluções } \\
\text { do programa e resolução } 95 \\
\text { - Legislação de pós-graduação } \\
\text { (UFSC e Capes) } \\
\text { - Necessidades pedagógicas } \\
\text { - Interesse social } \\
\text { - Técnico } \\
\text { - Diretrizes da Capes } \\
\text { - Gestão universitária } \\
\text { - Requisitos necessários } \\
\text { - Regras da Capes } \\
\text { - Estrutura do Programa } \\
\text { - "Ponto de saturação" } \\
\text { - Avaliação da Capes } \\
\text { - Currículo do curso } \\
\text { - APCN }\end{array}$ & $\begin{array}{l}\text { - Pesquisa e desenvolvimen- } \\
\text { to } \\
\text { - Gestão do tempo } \\
\text { - Levantamento de dados } \\
\text { sobre cursos } \\
\text { - Trabalhar em equipe } \\
\text { - Comunicação escrita } \\
\text { - Compreender a lógica das } \\
\text { legislações } \\
\text { - Dar coesão ao texto } \\
\text { - Planejamento } \\
\text { - Criar curso } \\
\text { - Experiência } \\
\text { - Trâmites burocráticos } \\
\text { - Controle } \\
\text { - Organização } \\
\text { - Envolvimento político junto } \\
\text { à Capes } \\
\text { - Capacidade analítica } \\
\text { - Tomada de decisão }\end{array}$ & $\begin{array}{l}\text { - Empreender } \\
\text { - Clareza } \\
\text { - Detalhamento } \\
\text { - Cumprimento de } \\
\text { prazos - frágil } \\
\text { - Ser líder } \\
\text { - Ser motivador } \\
\text { - Desejo de estar en- } \\
\text { volvido no processo } \\
\text { - Colocar a mão na } \\
\text { massa } \\
\text { - Proatividade } \\
\text { - Vontade } \\
\text { - Ser inovador } \\
\text { - Ser criativo } \\
\text { - Proatividade } \\
\text { - Iniciativa }\end{array}$ \\
\hline
\end{tabular}




\begin{tabular}{|c|c|c|c|}
\hline $\begin{array}{l}\text { Objetivos do Planeja- } \\
\text { mento Estratégico }\end{array}$ & Conhecimentos & Habilidades & Atitudes \\
\hline $\begin{array}{l}\text { 14- Criar Imersão } \\
\text { Profissional }\end{array}$ & $\begin{array}{l}\text { - Metodologias ativas } \\
\text { - Como escrever resolução } \\
\text { - Proposta do programa } \\
\text { - Gestão de processos } \\
\text { - Perfil desejado do egresso } \\
\text { - Lei de estágio } \\
\text { - Legislações } \\
\text { - Perfil do aluno } \\
\text { - O que se quer de egresso } \\
\text { - O que são Programas profis- } \\
\text { sionais } \\
\text { - Técnico } \\
\text { - Diretrizes da Capes } \\
\text { - Gestão universitária } \\
\text { - Anseios pedagógicos } \\
\text { - Imersão profissional } \\
\text { - Identificar áreas }\end{array}$ & $\begin{array}{l}\text { - Pesquisa e desenvolvimen- } \\
\text { to } \\
\text { - Gestão do tempo } \\
\text { - Analítica } \\
\text { - Lógica } \\
\text { - Comunicação escrita } \\
\text { - Como construir textos } \\
\text { legais } \\
\text { - Contato com gestores } \\
\text { - Conceitual } \\
\text { - Capacidade analítica } \\
\text { - Planejamento } \\
\text { - Comunicação }\end{array}$ & $\begin{array}{l}\text { - Empreender } \\
\text { - Clareza } \\
\text { - Detalhamento } \\
\text { - Comprometimento } \\
\text { - Vontade } \\
\text { - Proatividade } \\
\text { - Ser inovador } \\
\text { - Ser criativo } \\
\text { - Iniciativa }\end{array}$ \\
\hline $\begin{array}{l}\text { 16- Instituir a Ges- } \\
\text { tão de Egressos }\end{array}$ & $\begin{array}{l}\text { - Proposta do programa } \\
\text { - Perfil do discente } \\
\text { - Perfil do egresso } \\
\text { - Perfil desejado do egresso } \\
\text { - Área de conhecimento } \\
\text { - Relatórios de gestão de } \\
\text { egressos } \\
\text { - Gestão de egressos } \\
\text { - Técnicas } \\
\text { - Conhecer o egresso } \\
\text { - Formas de fazer } \\
\text { - Banco de dados } \\
\text { - T.l. } \\
\text { - Técnico } \\
\text { - Importância } \\
\text { - Justificativa } \\
\text { - Área } \\
\text { - Sistema } \\
\text { - Plataforma } \\
\text { - Onde estão os egressos } \\
\text { - Exigências da Capes }\end{array}$ & $\begin{array}{l}\text { - Gestão do tempo } \\
\text { - Planejamento } \\
\text { - Comunicação escrita } \\
\text { - Comunicação oral } \\
\text { - Trabalho em equipe } \\
\text { - Ouvir } \\
\text { - Visão do todo } \\
\text { - Gestão de projetos } \\
\text { - Sensibilização } \\
\text { - Criação de vínculos } \\
\text { - Saber ouvir } \\
\text { - T.l. } \\
\text { - Sistema para agilizar } \\
\text { - Analisar onde o egresso } \\
\text { está inserido e como pode } \\
\text { auxiliar } \\
\text { - Organização }\end{array}$ & $\begin{array}{l}\text { - Proatividade } \\
\text { - Comprometimento } \\
\text { - Ser motivador } \\
\text { - Contato com o } \\
\text { egresso } \\
\text { - Ser estimulador } \\
\text { - Constante comuni- } \\
\text { cação } \\
\text { - Estreitar relação } \\
\text { com egressos } \\
\text { - Criatividade } \\
\text { - Como fazer gestão } \\
\text { de egressos } \\
\text { - Iniciativa }\end{array}$ \\
\hline
\end{tabular}

Fonte: Dados primários elaborado pelos autores (2020).

A partir do momento em que se possui os indicadores, deve-se tomar cuidado para que a listagem não seja rasa demais ou então com diversos itens que na prática sequer serão considerados. Esse cuidado é pertinente porque ele deve refletir os conceitos de trabalho prescrito versus trabalho realizado. No caso das competências, não é recomendável se generalizar tudo, mas customizar. Logo, quanto maior for o detalhamento dos indicadores, melhor, pois assim evita-se interpretações difusas por parte de outras pessoas que não necessariamente conhecem do assunto, mas vão utilizar o produto do mesmo, bem como pessoas que conhecem e resolvem adotar outros indicadores que sequer foram considerados na listagem. 
Uma vez que a relação está pronta, o correto é validá-la com os responsáveis pelo programa para que ela sirva como uma referência de consulta e posterior comparação quando se pensa em ações de gestão por competências.

Um dos resultados observados na pesquisa vai de encontro com o que defende Rios Neto (2016) ao afirmar que a universidade é diferenciada das demais organizações, pois é uma organização complexa e o mapeamento das competências mostrou essa característica.

Diante das inúmeras possibilidades e visando atender o objetivo de sugerir ações de encaminhamento após a conclusão desta primeira etapa do mapeamento para os gestores e membros envolvidos nas ações estratégicas do PPGAU, entende-se que este quadro final poderá ser utilizado para:

- Identificação do grau de competência de cada membro do colegiado pleno para que se tenha um mapa estratégico de pontencialidades pessoais visando trabalhar objetivos e estratégias de ação cada vez mais ousados e pertinentes ao Programa;

- Adequação do perfil dos envolvidos com as ações resultantes dos objetivos apresentados no planejamento estratégico do PPGAU. O mapeamento de competências pode auxiliar na identificação do perfil ideal para a execução de ações que culminam nos objetivos do planejamento estratégico. A partir do momento em que foram identificados o rol de Conhecimentos, as Habilidades e Atitudes necessários para o atingimento de cada objetivo há maior facilidade em identificar as características mais adequadas dentre os indivíduos que compõem do Colegiado Pleno do PPGAU para o atingimento dos objetivos e metas;

- Planejar ações de treinamento e formação para capacitar indivíduos almejando executar ações com base nas competências necessárias já mapeadas. A definição dos membros responsáveis pelo atingimento dos objetivos pode estar alinhada com as competências mapeadas, com o intuito de tornar mais eficaz e eficiente a execução. Nesse sentido, o programa PPGAU pode ofertar ações destas naturezas, ou então a própria UFSC, uma vez que os membros do Colegiado são seus funcionários;

- Proporcionar subsídios para que futuros docentes e discentes possam saber quais características de competências são procuradas pelo Programa e, assim, desenvolverem as mesmas buscando investir em suas carreiras profissonais mediante ocupação de cargos de gestão ou então investimento em conhecimentos específicos;

- Dentre outras. 
Em síntese, são ações inerentes à Gestão de Pessoas por competências que devem estar alinhadas ao que se planeja.

\section{CONCLUSÕES}

O objetivo deste artigo científico foi identificar quais são as competências necessárias aos membros do Colegiado Pleno do Programa de Pós-Graduação em Administração Universitária da Universidade Federal de Santa Catarina para a realização das ações previstas em seu planejamento estratégico.

Este estudo buscou contribuir com o desenvolvimento científico a partir da aplicação customizada de parte da temática inerente à Gestão de Competências no campo das universidades. Percebe-se, primeiro, um futuro que evidenciará gradativamente a aludida área como requisito fundamental para o atingimento da excelência no âmbito das organizações, seja de natureza empresarial, governamental ou universitária. Em segundo, que determinadas contribuições científicas são indispensáveis aos gestores acadêmicos para ampliar o leque de ferramentas disponíveis para o exercício profissionalizado no cotidiano da gestão universitária.

É relevante destacar as contribuições da Gestão por Competências no âmbito do planejamento estratégico, tendo em vista que a primeira pode ser um condicionador da concretização, acompanhamento e ajuizamento da segunda. Além disso, os estudos sobre Gestão por Competências no âmbito das organizações universitárias estão avançando gradativamente. No caso deste trabalho, entende-se que ele contribui com uma pequena parcela no desenvolvimento da temática nas instituições de ensino que contenham programas de Pós-Graduação. Todavia, estudos posteriores serão necessários para auxiliarem os gestores universitários a atingirem um grau satisfatório de excelência em seus respectivos campos de atuação.

Revisando os objetivos específicos delineados e apresentados neste documento, verifica-se que todos foram atingidos. Nesse sentido, espera-se que a partir do momento em que a organização estudada tenha uma noção mais clara das características de competências exigidas para o seu colegiado, novas ações de mapeamento sejam realizadas com os próprios sujeitos para verificar o hiato entre o modelo prescrito/validado e o existente.

Com isso, o programa terá condições de conhecer as potencialidades em termos de entrega por parte de seus membros do Colegiado e também poderá pensar estrategicamente em desenvolver e ofertar ações de capacitação customizadas para incrementar as competências de seu quadro pessoal e, por que não, da própria Universidade como um todo. 


\section{REFERÊNCIAS}

Brandão, H. P., \& Bahry, C. P. (2005). Gestão por competências: métodos e técnicas para mapeamento de competências. Revista do Serviço Público - RSP, 56(2), 179-194.

Brandão, H. P., Guimarães, T. A., \& Borges-Andrade, J. E. (2002). Competências emergentes na indústria bancária: um estudo de caso. Revista Comportamento Organizacional e Gestão, 8(2), 173-190.

Bruno-Faria, M. F., \& Brandão, H. P. (2003). Gestão de competências: identificação de competências relevantes a profissionais da Área T\&D de uma organização pública do Distrito Federal. Revista de Administração Contemporânea, 7(3), 35-36.

Carbone, P. P., Brandão, H. P., Leite, J. B. D., \& Vilhena, R. (2005). Gestão por competências e gestão do conhecimento. Rio de Janeiro: Ed. da Fundação Getúlio Vargas.

Dalmau, M. B. L. (2019). Disciplina de Gestão por Competências em IES. Programa de Pós-Graduação em Administração Universitária. UFSC.

Escola Nacional de Administração Pública. (2005). Relatório de gestão 2005. https://repositorio.enap.gov.br/handle/1/703.

Escola Nacional de Administração Pública. (2009). Mesa-redonda de pesquisa-ação. https://repositorio.enap.gov.br/bitstream/1/398/1/livro_mesa_redonda.pdf.

Escola Nacional de Administração Pública. (2020). Regulamento pré-seleção para o cargo de Coordenador-Geral de Pós-Graduação Stricto Sensu. https://enap.gov.br/media_files/ documentos/processos-seletivos/DGI/Regulamento_03_04_atualizacao_cronograma.pdf.

Fleury, M. T. L., \& Fleury, A. (2001). Construindo o conceito de competência. Revista de administração contemporânea, 5(SPE), 183-196.

lenaga, C. H. (1998). Competence based management: seminário executivo. São Paulo: Dextron Consultoria Empresarial.

Madruga, R. (2018). Treinamento e desenvolvimento com foco em educação corporativa. São Paulo: Saraiva.

Mcclelland, D. (1973). Testing for competence rather than for intelligence. American Psychologist, January.

Pereira, M. F. (2010). Planejamento estratégico: teorias, modelos e processos. São Paulo: Atlas.

Richardson, R. J. et al. (1999). Pesquisa social: métodos e técnicas. São Paulo: Atlas. 
Rios Neto, A. S. (2016). Complexidade nas Organizações. http://www.amb.com.br/portal/ docs/artigos/Artigo\%20-\%20Complexidade\%20nas\%20Organiza.pdf.

Sparrow, P. R., \& Bognanno, M. (1994). Competency requirement forecasting: issues for international selection and assessment. In C. Mabey, \& P. Iles. (Orgs.). Managing learning. London : Routledge.

Universidade Federal de Santa Catarina. (2017). Programa de Pós-Graduação em Administração Universitária. Legislação. Regimento do PPGAU. http://ppgau.paginas.ufsc.br/ files/2017/11/Regimento-Final-PPGAU-Processo-n\%C2\%BA-23080.042491-2017-75-PublicadoBO.pdf.

Universidade Federal de Santa Catarina. (2019). Programa de Pós-Graduação em Administração Universitária. Planejamento Estratégico do PPGAU. https://repositorio.ufsc.br/ bitstream/handle/123456789/196427/2\%20-\%2024052019\%20-\%2OPlanejamento\%2OEstrat\%c3\%a9gico\%20AprovadoAssinado.pdf?sequence $=1 \&$ isAllowed $=y$.

Vergara, S. M. (2014). Projetos e relatórios de pesquisa em administração. São Paulo: Atlas.

Zarifian, P. (2001). Objetivo competência: por uma nova lógica. São Paulo: Atlas. 


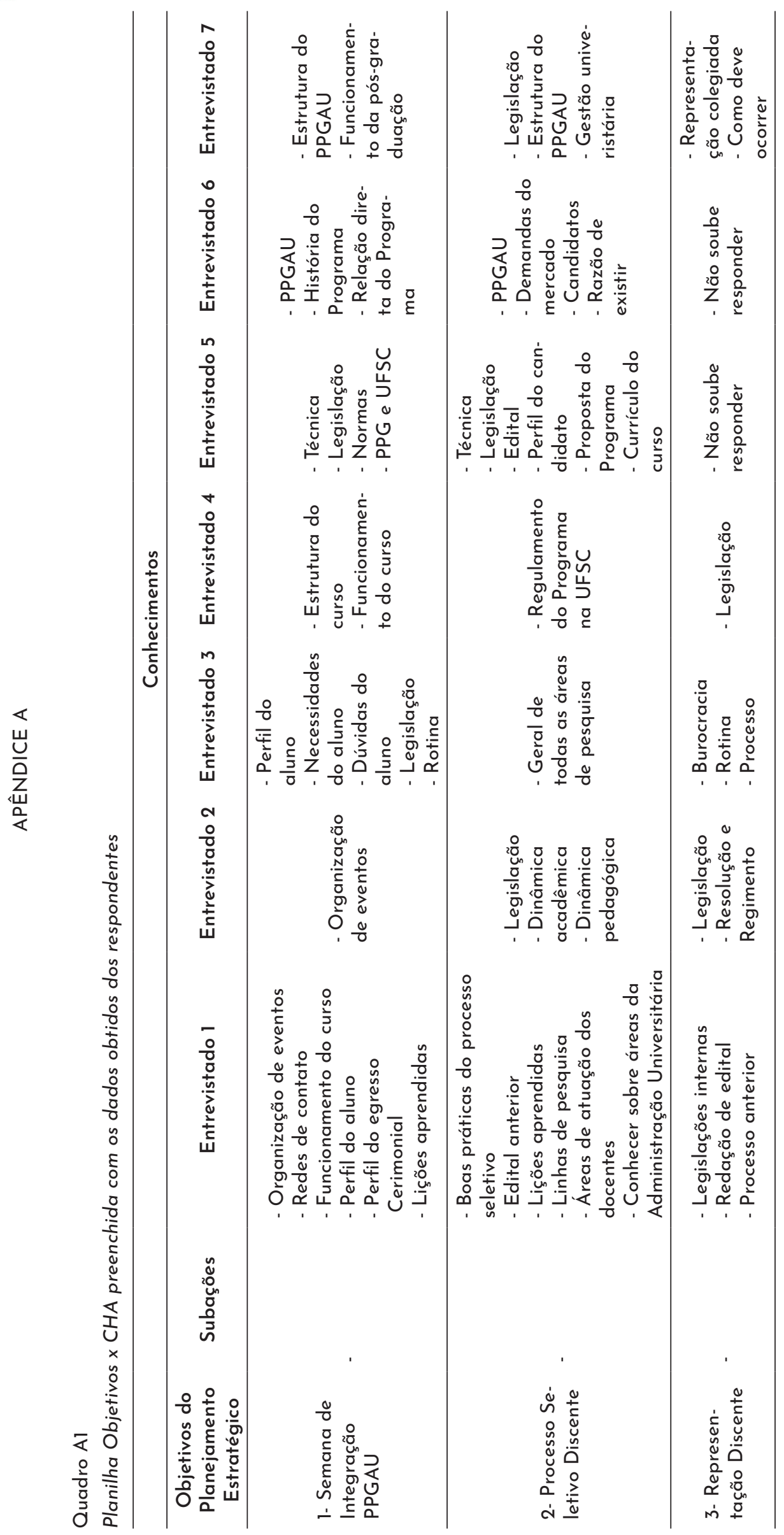




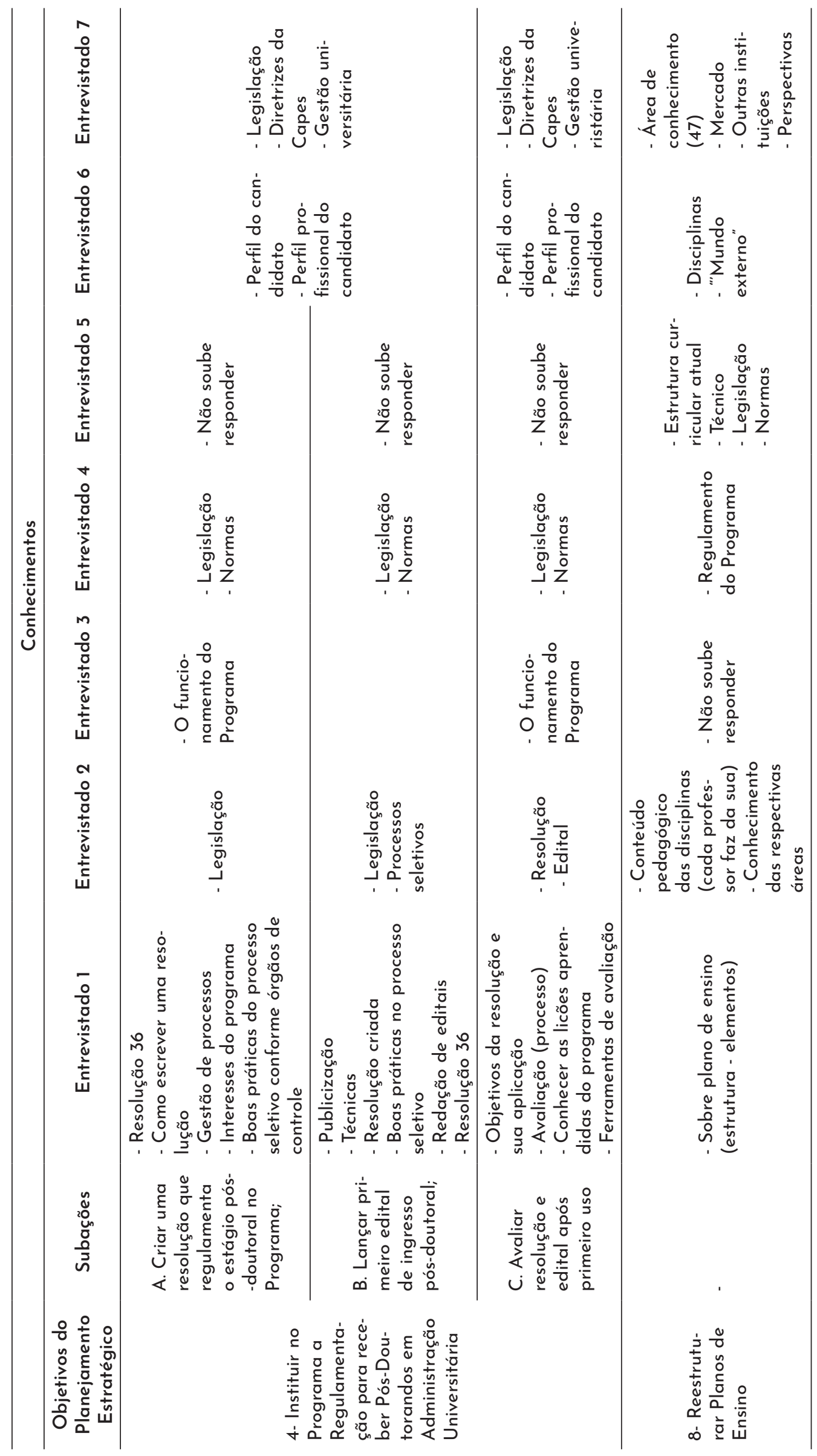




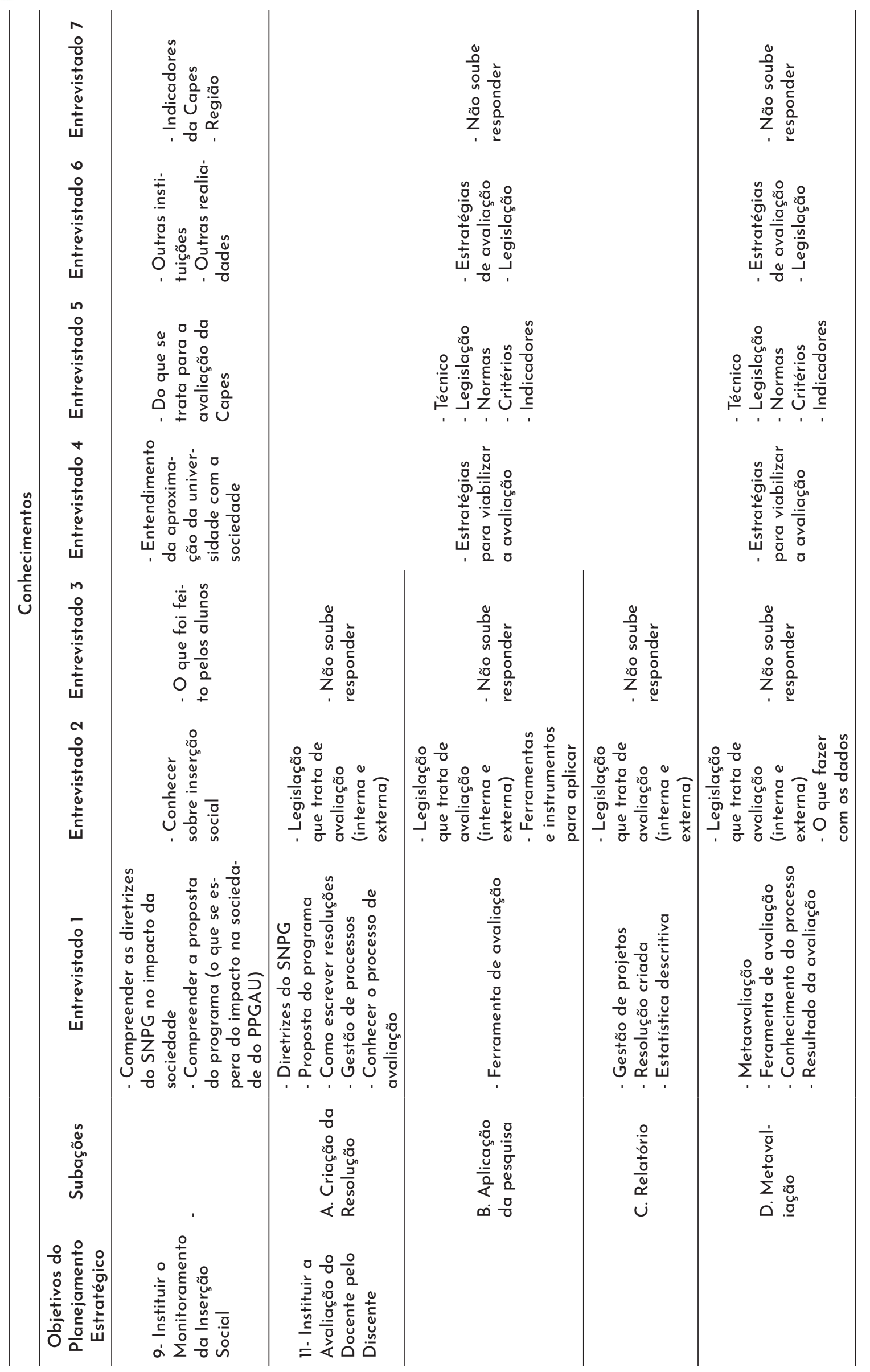




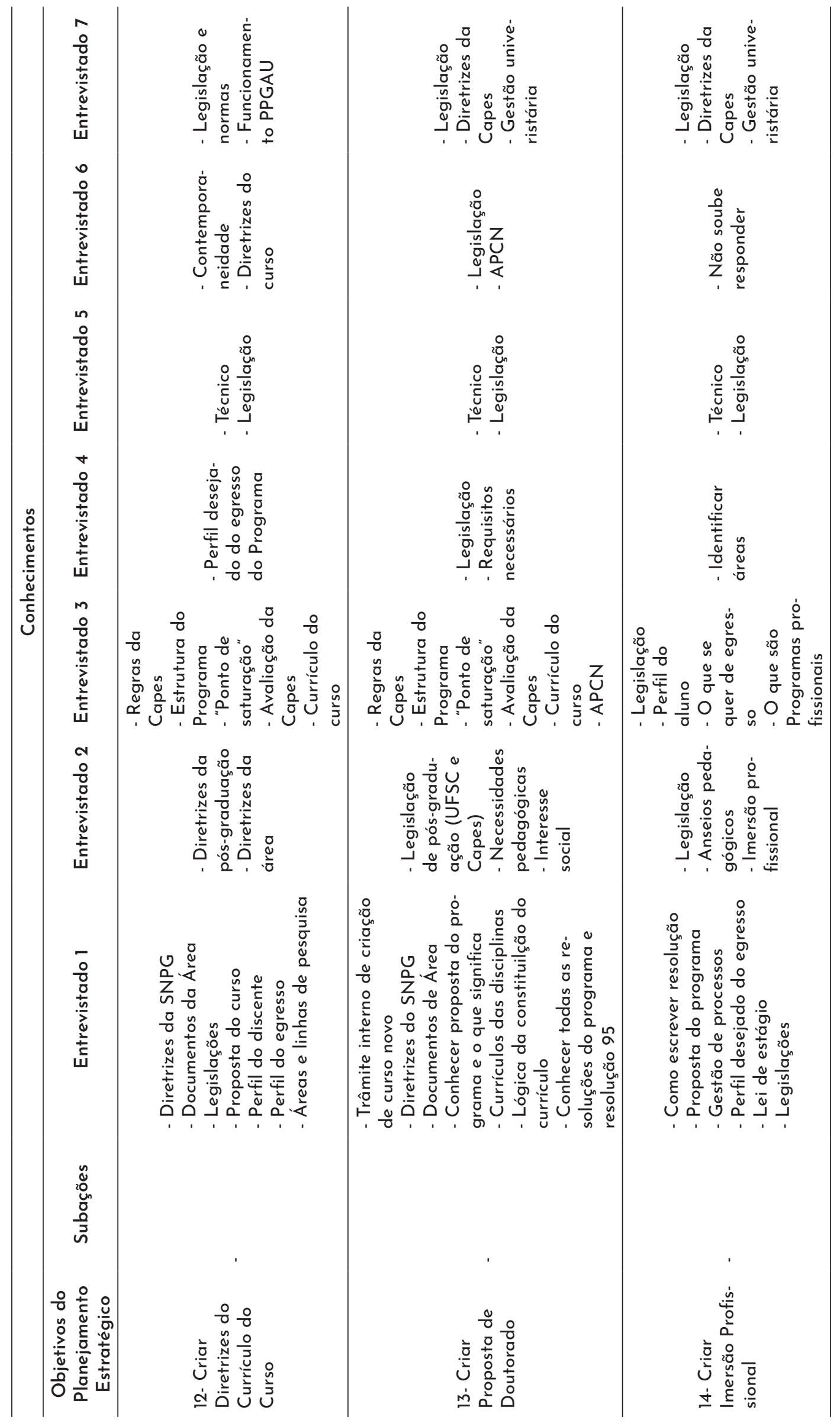




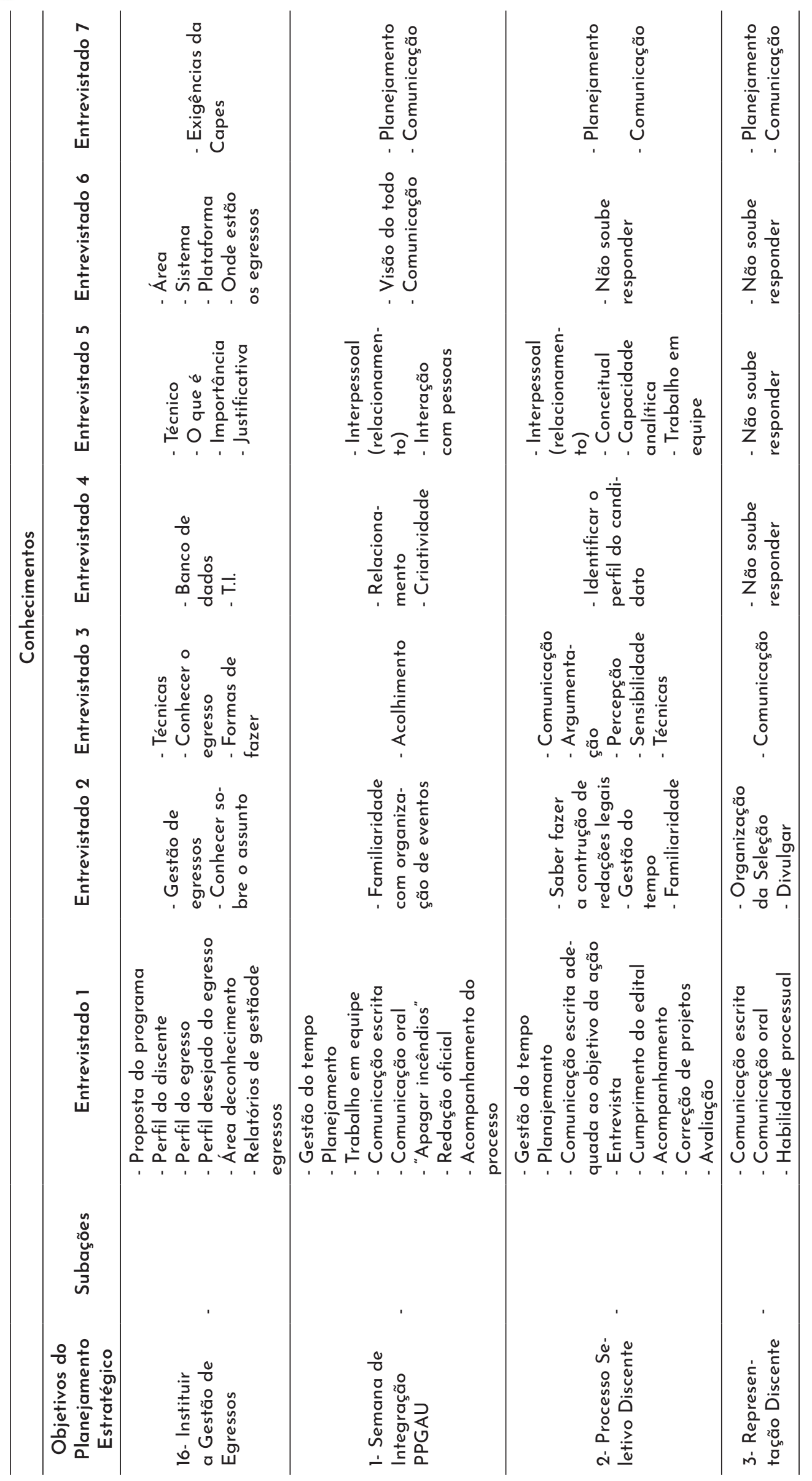




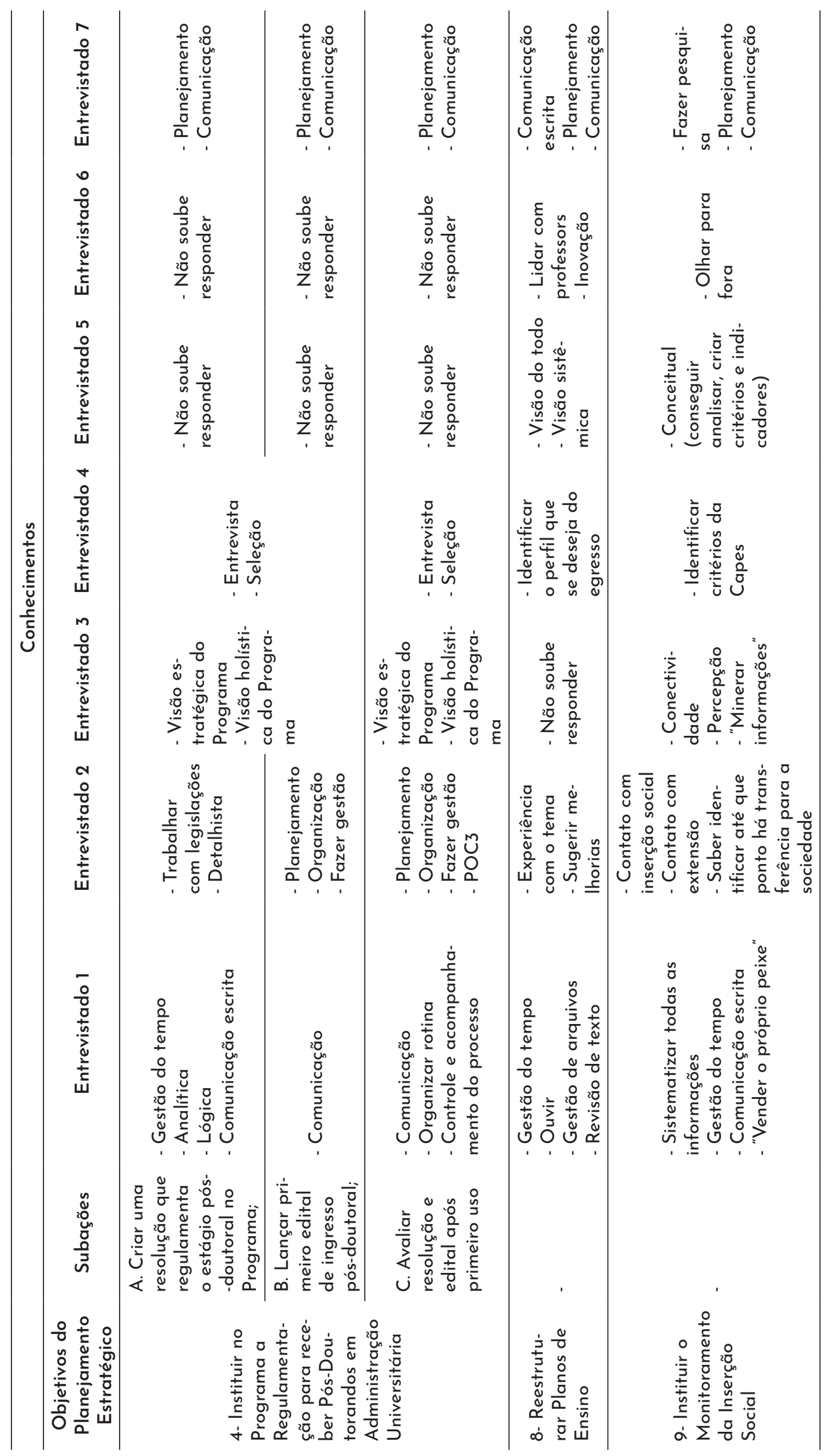




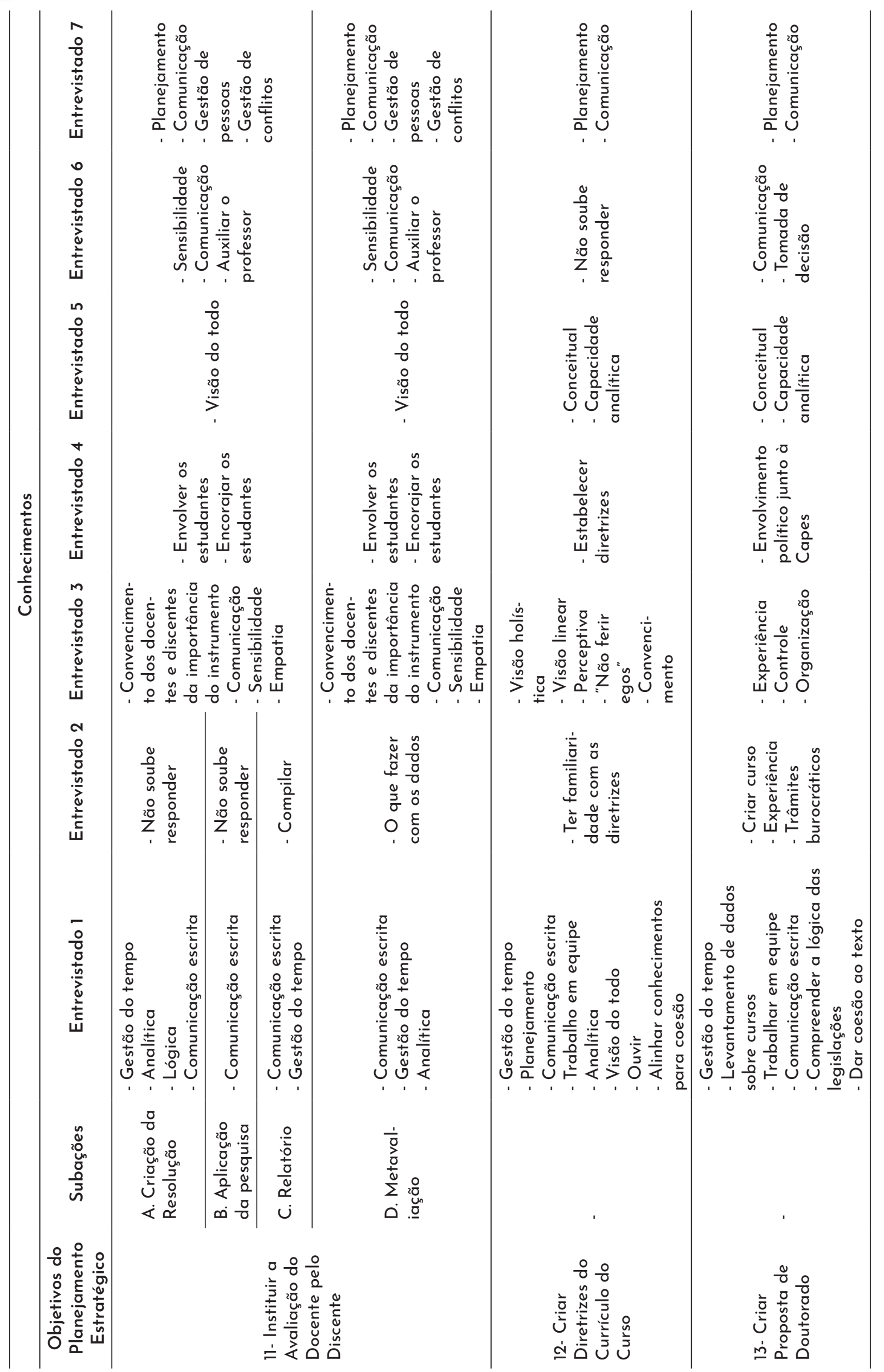




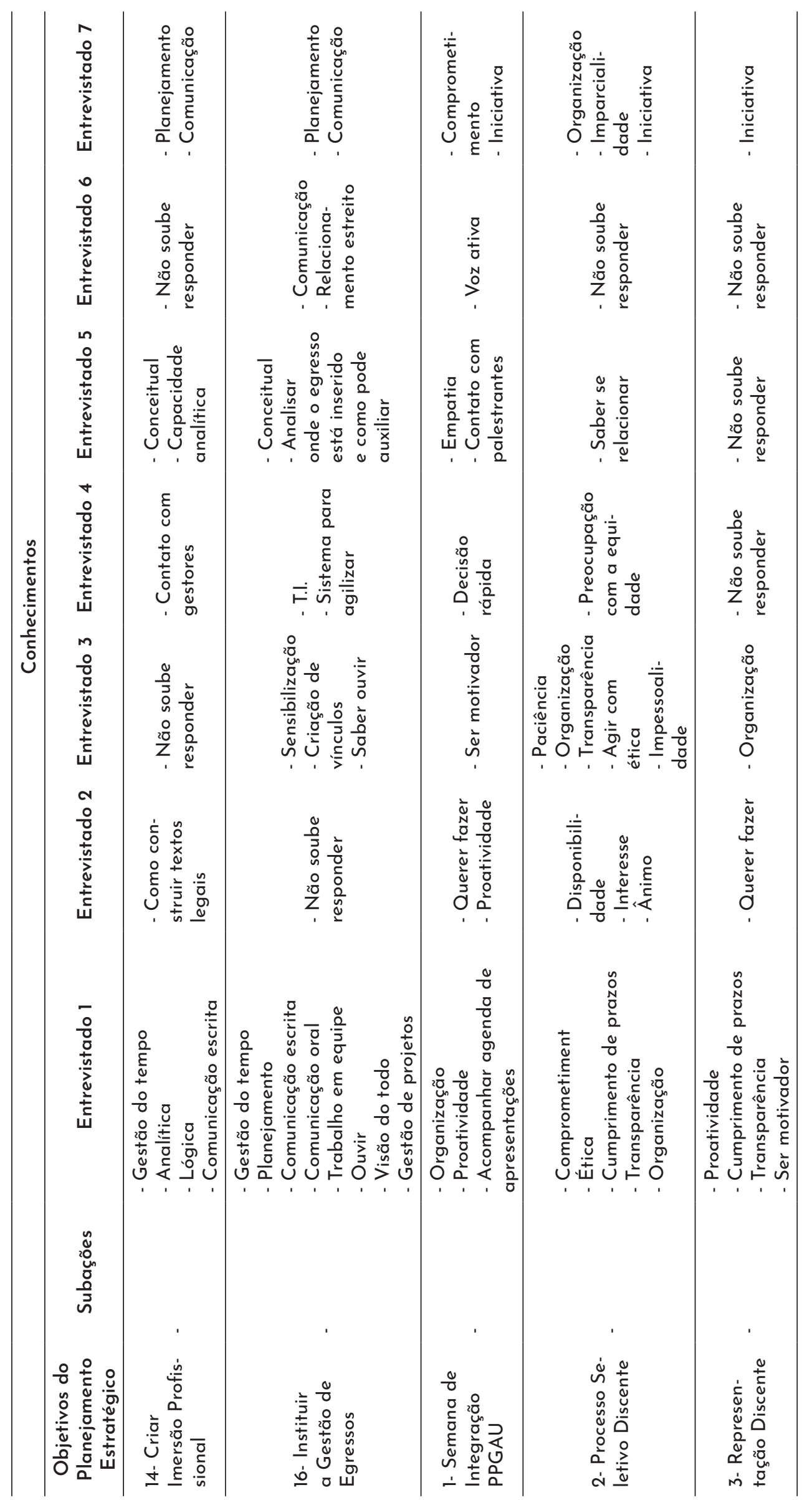




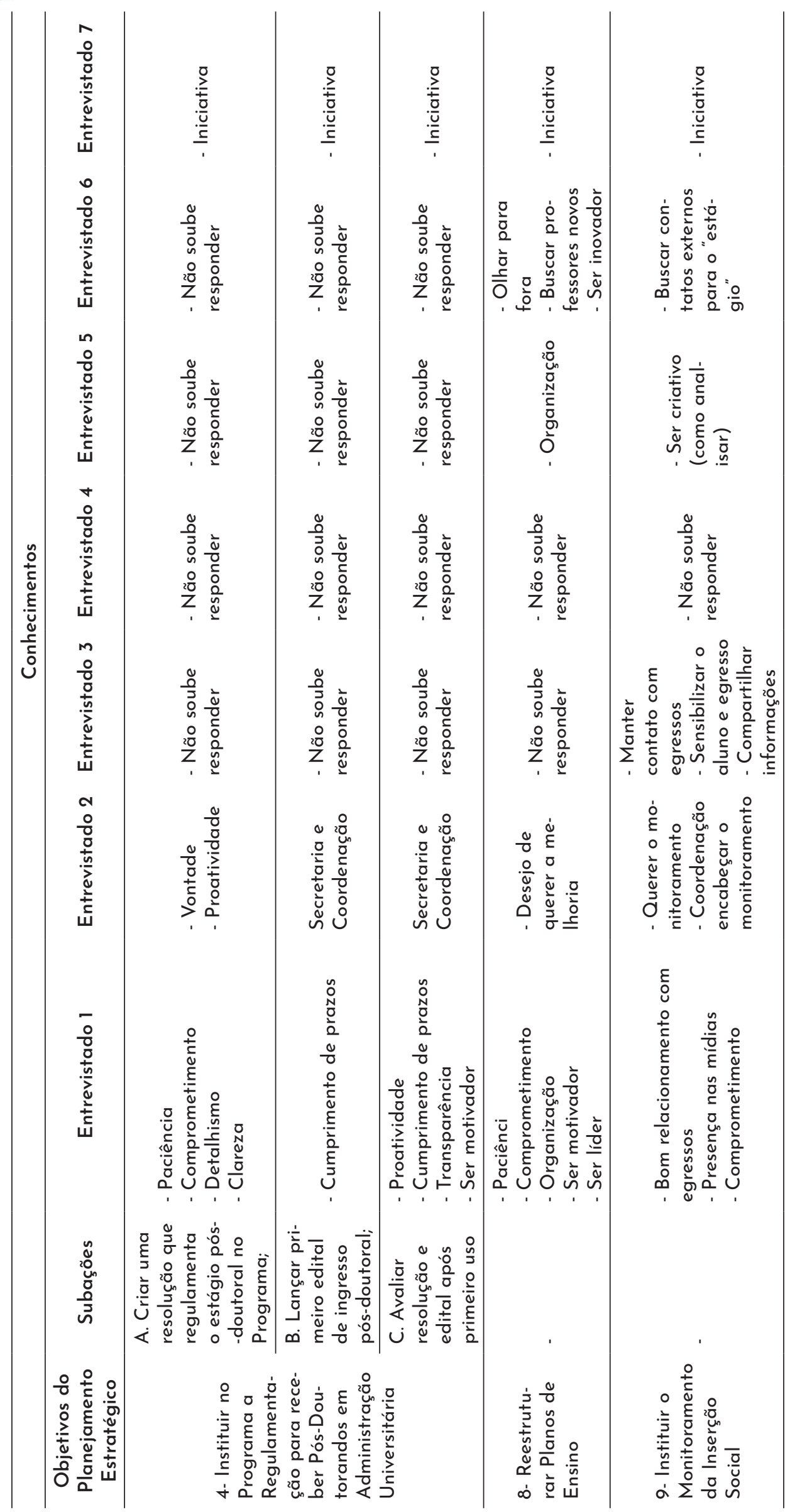




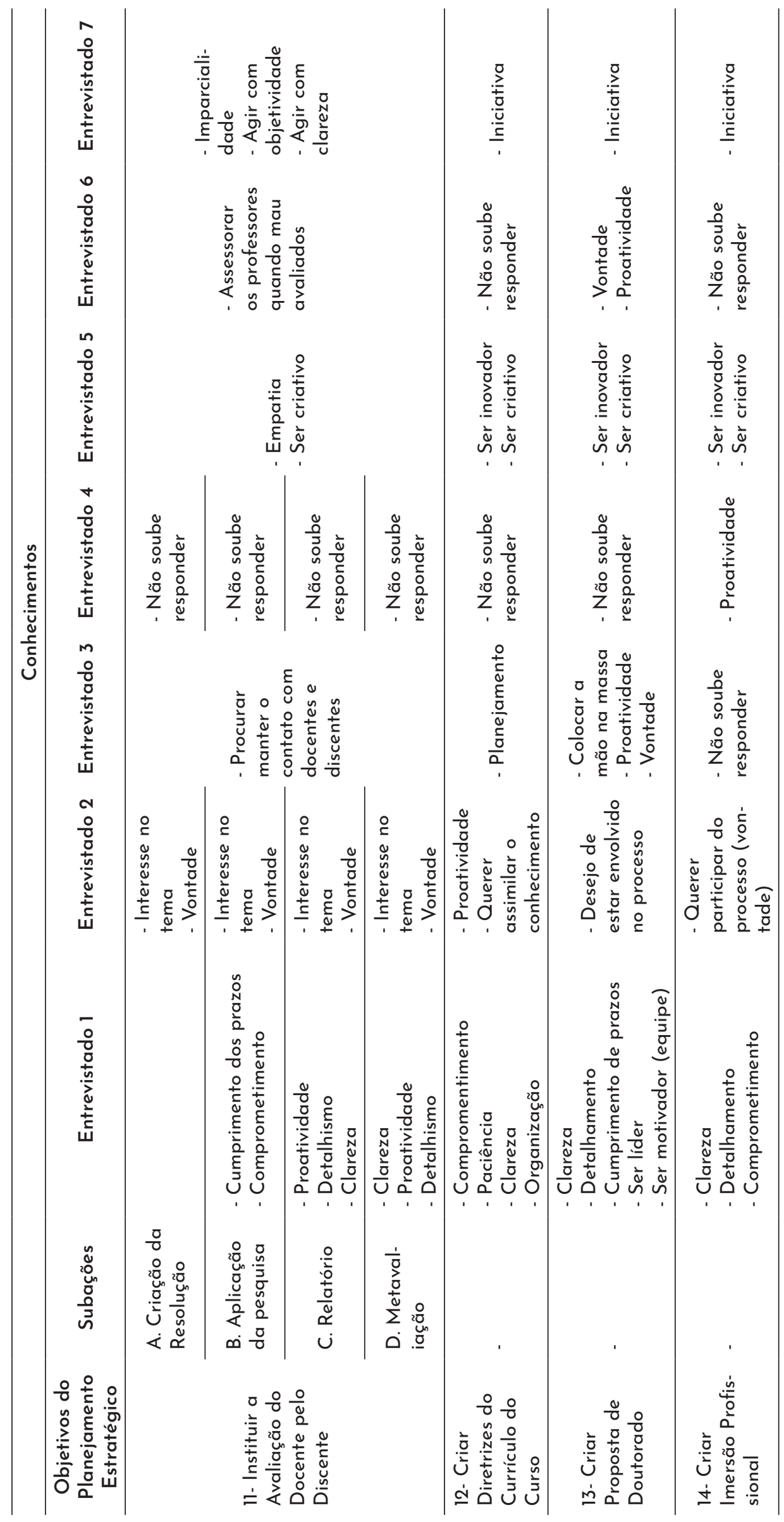




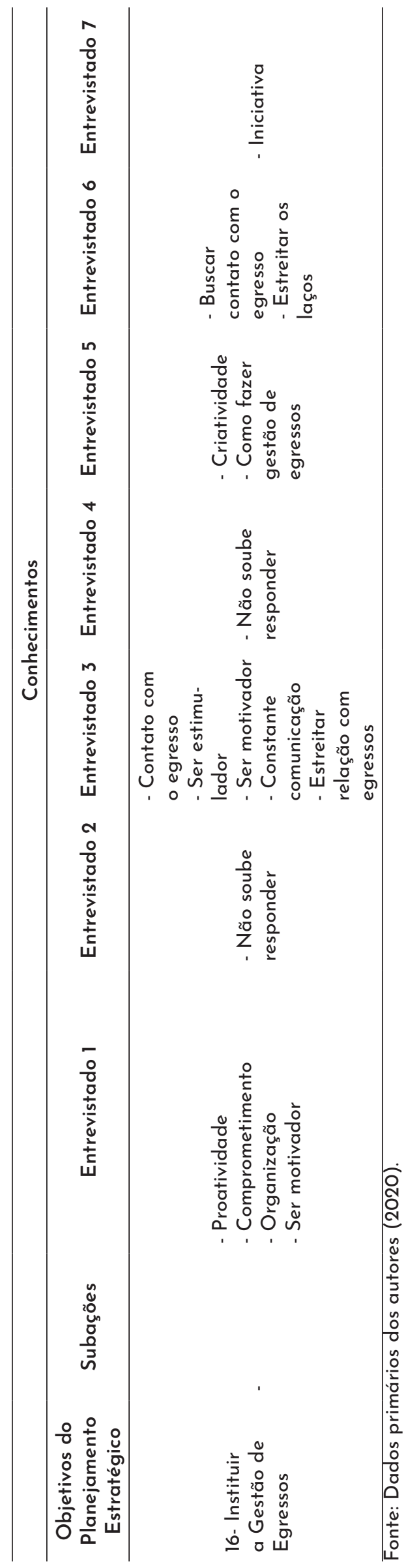

